Advanced Industrial Materials (AIM) Program Office of Industrial Technologies

Energy Efficiency and Renewable Energy

U.S. Department of Energy (DOE)

\title{
Advanced Industrial Materials (AIM) \\ Program
}

\section{Compilation of Project Summaries and Significant Accomplishments FY 1999}

Date Published: May 2000

Coordinated by Peter Angelini

Compiled by Gwen Sims Metals and Ceramics Division Oak Ridge National Laboratory

Prepared by the Oak Ridge National Laboratory

Oak Ridge, Tennessee 37831

for the U.S. Department of Energy

under contract number DE-AC05-00OR22725 



\section{TABLE OF CONTENTS}

Page

\section{INTRODUCTION}

Introduction to the Advanced Industrial Materials (AIM) Program

C. A. Sorrell

\section{AdvanCed Ceramics AND COMPOSITES}

On-Line Chemical Vapor Deposition of Coatings on Float Glass (supported by OIT Glass Vision Team)

M. D. Allendorf

Materials for High-Temperature Filtration/Thermochemical Modeling

T. M. Besmann and C. Y. Jones

High-Temperature Facilitated Transport Membranes

D. J. Devlin

Membrane Systems for Energy-Efficient Separation of Light Gases

D. J. Devlin

New Method for Synthesis of Metal Carbides, Nitrides, and Carbonitrides

R. Koc.

Synthesis and Processing of Composites by Reactive Metal Penetration

R. E. Loehman, W. G. Fahrenholtz, P. Lu, and S. M. Johnson

\section{AdVANCED INTERMETALLICS/METALS AND COMPOSITES}

Advanced Ordered Intermetallic Alloy Development

C. T. Liu and J. H. Zhu .

Advanced Iron- and-Nickel-Based Alloys

P. J. Maziasz and R. W. Swindeman

High-Density Infrared Processing of Materials

C. A. Blue and V. K. Sikka.

Intermetallic Alloy Development and Technology Transfer (partial support also from Steel Vision Team)

V. K. Sikka and M. L. Santella 


\section{ADVANCED INTERMETALLICS/METALS AND COMPOSITES (continued)}

Materials for the Pulp and Paper Industry

J. R. Keiser

Synthesis and Design of Silicide Intermetallic Materials (supported by OIT Glass Vision Team)

J. J. Petrovic and R. G. Castro

Uniform-Droplet Spray Forming

V. K. Sikka, C. A. Blue, J.-H. Chun, and T. Ando

\section{NeW Materials AND Processes}

Advanced Industrial Materials (AIM) Fellowship Program

K. Ketner, D. K. Hoffman, R. B. Thompson, I. E. Anderson

S. McElroy, R. Reddy, T. E. Bloomer, P. J. Maziasz, and V. K. Sikka

Advanced Materials for High-Temperature Liquid-Metal Corrosion and

Erosion Resistance

M. Trkula and M. A. Nastasi

Development of Improved Refractories (partial support from OIT Glass Vision Team)

A. A. Wereszczak, K. C. Liu, B. A. Pint, M. Karakus, and R. E. Moore

Metals Processing Laboratory User (MPLUS) Facility

G. Mackiewicz-Ludtka

Microwave Joining of SiC

R. Silberglitt

Selective Inorganic Thin Films

T. M. Nenoff .85

\section{PolyMers}

Polymer Electrolyte Electrochemical Reactors of Lowered Energy Consumption

S. Gottesfeld. 
INTRODUCTION 



\section{Introduction to the Advanced Industrial Materials (AIM) Program Office of Industrial Technologies Fiscal Year 1999}

\section{A. Sorrell, Program Manager}

$\mathrm{F}$ or the past 10 years the Advanced Industrial Materials (AIM) has supported development of new and improved materials to enable U.S. industry to improve energy efficiency, increase productivity, and reduce waste. It has been a National Laboratory based program, with work currently under way at Oak Ridge National Laboratory, Los Alamos National Laboratory, and Sandia National Laboratories, in collaboration with industrial and university partners. With the advent of the Industries of the Future (IOF) strategy within the Office of Industrial Technologies (OIT) and the scheduled completion of the Continuous Fiber Ceramic Composites (CFCC) Program in FY 2002, an integrated materials program is being developed in OIT. So this represents the last summary of AIM research and development.

The new program, Industrial Materials for the Future (IMF), will be competitive in operation, with solicitations for proposals for development of materials in accordance with the IOF Technology Roadmaps, followed by merit review and funding of the best proposals. Industry will take the lead in "industry-specific" research and development, in cooperation with National Laboratories, as needed. National Laboratories and universities will take the lead in maintaining a base technology program, for the purpose of maintaining a continuing flow of new materials technologies. The AIM and CFCC Programs will be replaced by the IMF program over a three year period, so that in FY 2004, all research and development will be in response to industry solicitations and Laboratory/university calls.

The Program Manager believes that AIM has been an extremely successful program, thanks to the Laboratory investigators and their partners. For 10 years, the program has increased industrial participation from very little to nearly 100 percent. The CFCC Program, similarly, has been successful in advancing the knowledge of processing and property development in these materials, though much still can be done in advancing their uses in industry. It is hoped that the Industrial Materials for the Future Program will be equally successful, not only in solving industry's short-term, immediate needs, but also in maintaining a materials technology base that will lead to longer-range materials and processing developments.

The projects summarized here will be carried to successful conclusions over the next 3 years and the current Laboratories in AIM and CFCC will be joined by other Laboratories, universities, and new industrial partners. The Program Manager expresses his profound appreciation for the very fine work done for OIT during the last 10 years. 



\section{ADVANCED CERAMICS AND COMPOSITES}





\section{PROJECT SUMMARY}

\section{ADVANCED INDUSTRIAL MATERIALS (AIM) PROGRAM}

\section{PROJECT TITLE: On-Line Chemical Vapor Deposition of Coatings on Float Glass \\ PHASE: FY 1999 \\ COMPLETION DATE:}

PERFORMING ORGANIZATION: Sandia National Laboratories, Livermore, California (project funded by the OIT Glass Vision Team)

PRINCIPAL INVESTIGATOR: Mark D. Allendorf (925-294-2895)

PHASE OBJECTIVE: To develop predictive computational models, process-control algorithms, and sensors for designing, optimizing, and operating coating processes for depositing energy-efficient coatings on float glass for architectural and automotive uses.

ULTIMATE OBJECTIVE: To improve the competitiveness of the U.S. float-glass industry by developing new, cost-effective uses of glass.

TECHNICAL APPROACH: Industrial methods for the deposition of coatings on float glass are simulated using a high-temperature, variable-pressure flow reactor constructed in this project. The reactor provides an environment in which such process parameters as temperature, pressure, chemical composition, and reactant mass-flow rates are tightly controlled. Access for mass-spectrometric sampling is provided. Parallel development of computational models of physical and chemical mechanisms of deposition is also conducted. Experimental data provide insight into the mechanism controlling deposition rates and deposit properties and are also used to test and verify the computational models.

\section{PROGRESS:}

- Characterized the thermal stability and reactivity of indium-containing precursors used in float-glass coating operations. Used these data to advise CRADA partner Libbey-Owens-Ford Co. (LOF) in laboratory development and pilot-scale testing of a new coating process. Data were analyzed and put into a form appropriate for publication in reviewed journals.

- Designed and constructed a field-portable version of a system for monitoring precursors and reaction by-products used in float-glass coating operations. The system is built around an economical, commercially available, miniature mass spectrometer that can be easily multiplexed to monitor gas concentrations at multiple locations.

- Transported the field-portable mass-spectrometer unit to an LOF float-glass facility in Ottawa, Illinois, and tested it during coating operations there. Results indicate that the device has sufficient sensitivity to detect many species of interest, both in coating operations and within the float bath.

- Identified compact and economical sensor for detecting hydrogen and oxygen in coating and float-bath operations. A field-portable unit was constructed in preparation for field testing in FY 2000. 


\section{PROJECT SUMMARY (continued)}

\section{PROJECT TITLE: On-Line Chemical Vapor Deposition of Coatings on Float Glass}

Patents: None

Publications: 7

Presentations: 6

\section{ACCOMPLISHMENTS:}

Technology Transfer: Completed the third year of a 3-year, \$1.06M CRADA with Libbey-Owens-Ford Co. (including $\$ 540 \mathrm{~K}$ of direct and in-kind funding from LOF). Provided LOF with data concerning coating and float-bath operations at their Ottawa, Illinois, float-glass facility obtained during field testing of the portable mass-spectrometer unit. Plans are now being developed to construct a second unit for use by LOF.

\section{Licenses: None}

CRITICAL ISSUES: In the production of float glass, increasing the energy efficiency of fenestration through high-performance on-line coatings is an important technological objective, not only for glass producers, but also window fabricators, architects, HVAC engineers, automobile manufacturers, and utilities. However, the complexity of industrial coating processes, coupled with the costs associated with process development, make it difficult to make more than incremental improvements in coating effectiveness and process efficiency. A more detailed understanding of the high-temperature processes occurring prior to coating formation is necessary to effect a quantum leap in coating performance. In addition, this knowledge is needed to develop advanced methods for process control to improve product quality, reduce waste, and lower processing costs.

FUTURE PLANS: Field tests of solid-state hydrogen and oxygen sensors in a float-glass facility owned by LOF are planned for FY 2000. Discussions are under way to extend the CRADA with LOF, with a key objective being the construction of a portable massspectrometer gas-monitoring unit for use by LOF. We also will be conducting a workshop for the DOE Office of Industrial Technologies to develop a technology roadmap for coating on glass.

POTENTIAL PAYOFF: Very few new on-line coating technologies have been developed for float glass due to the high-design and start-up costs. Use of the experimental data and computational models developed here is expected to shorten the time required to design, optimize, and scale up new coating processes and to facilitate extension of existing technology to new materials. New sensor hardware currently under development will increase the efficiency of coating operations by notifying operators of conditions that lead to sudden process upsets, thus minimizing downtime.

ESTIMATED ENERGY SAVINGS: New coatings on float glass developed in this project will save $1.4 \times 10^{19} \mathrm{Btu} /$ year when installed in place of clear glass windows. Energy benefits associated with widespread use of CFCCs are large. Examples include: up to 0.52 Quads/year in gas turbines, 0.5 Quads/year in high-pressure heat exchangers, 0.1 Quads/year in hot-gas cleaning systems, and 0.5 Quads/year in radiant burners used in the metals and glass industries. 


\title{
SIGNIFICANT ACCOMPLISHMENT
}

\section{ADVANCED INDUSTRIAL MATERIALS (AIM) PROGRAM}

\author{
Theory and Experiment Establish Thermal Stability \\ of Key Organometallic Compound
}

PROBLEM: The cost and complexity of industrial processes for depositing coatings on float glass make it difficult to achieve substantial improvements in coating composition and process efficiency. A detailed understanding of the high-temperature chemistry occurring prior to coating formation is necessary to effect a quantum leap in coating performance. This knowledge is also needed to develop novel methods to improve product quality, reduce waste, and lower costs.

RESULTS: Quantum-level calculations using ab initio methods have been used to predict thermochemical properties for methyl-indium species important to CVD coating operations. The results suggest that previously measured heats of formation and bond dissociation energies for trimethylindium (TMI) are in error. Experiments in a hightemperature flow reactor, equipped with sophisticated molecular-beam mass-sampling equipment, substantiate the ab initio predictions by revealing for the first time an autocatalytic process governing TMI decomposition. This observation invalidates prior experimental methods used to measure TMI thermochemistry and thereby establishes a new metric for its thermal stability. Furthermore, methods developed herein can be used to generate reliable thermodynamic and kinetic information needed to build computational models for simulating coating processes.

Table 1. Comparison between heats of formation and bond dissociation energies (BDE)*

\begin{tabular}{|c|c|c|}
\hline \multirow[b]{2}{*}{ compound } & \multicolumn{2}{|c|}{$\Delta \mathrm{H}_{\mathrm{f}}^{\circ}(298 \mathrm{~K}) \mathrm{kcal} / \mathrm{mol}$} \\
\hline & calculated & measured \\
\hline $\mathrm{In}\left(\mathrm{CH}_{3}\right)_{3}$ & 20.20 & $41.44,40.8,47.9$ \\
\hline $\operatorname{In}\left(\mathrm{CH}_{3}\right)_{2}$ & 50.21 & \\
\hline \multirow[t]{2}{*}{$\mathrm{InCH}_{3}$} & 40.26 & \\
\hline & \multicolumn{2}{|c|}{ BDE kcal $/ \mathrm{mol}$} \\
\hline bond & calculated & measured \\
\hline$\left(\mathrm{CH}_{3}\right)_{2} \mathrm{In}_{-} \mathrm{CH}_{3}$ & 65.07 & 47.2 \\
\hline $\mathrm{CH}_{3} \mathrm{In}-\mathrm{CH}_{3}$ & 25.11 & 28.8 \\
\hline $\mathrm{In}-\mathrm{CH}_{3}$ & 52.80 & 40.7 \\
\hline mean In- $\mathrm{CH}_{3}$ & 47.66 & 38.9 \\
\hline
\end{tabular}

*For methyl-indium compounds relevant to glasscoating operations.

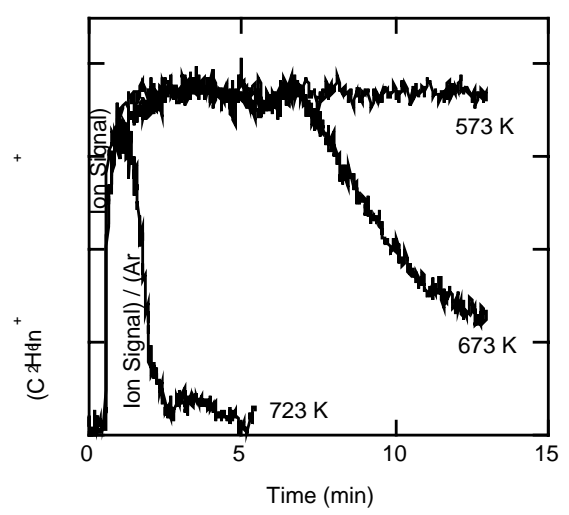

Fig. 1. Ion signal as a function of reaction time for tri-methyl-indium (TMI) in helium at three different reactor temperatures, showing that TMI decom-position is an autocatalytic process preceded by a short induction period.

SIGNIFICANCE - FOR ENERGY EFFICIENCY: In North America, 2.6 million tons/year of float glass are used in residential and commercial construction. Use of socalled "low-E" (for "low emissivity") coatings on this glass can dramatically improve the energy efficiency of this material. New coatings developed in this project will save $1.4 \times$ $10^{12} \mathrm{Btu} /$ year when installed in place of clear glass windows. 



\section{PROJECT SUMMARY}

\section{ADVANCED INDUSTRIAL MATERIALS (AIM) PROGRAM}

\section{PROJECT TITLE: Materials for High-Temperature Filtration/Thermochemical Modeling}

PHASE: FY 1999

\section{COMPLETION DATE:}

PERFORMING ORGANIZATION: Oak Ridge National Laboratory

PRINCIPAL INVESTIGATORS: Theodore M. Besmann/ORNL (865-574-6852) and Camille Y. Jones (865-574-1057)

PHASE OBJECTIVE: An objective of the current year's work was to perform benchscale testing of the compatibility of high-temperature filters in the Dow Corning applications. Another objective was to develop a method for computational thermodynamic modeling of a molten salt system $\left[\mathrm{Na}^{+}, \mathrm{K}^{+} / \mathrm{Cl}^{-}, \mathrm{S}^{2-}, \mathrm{SO}^{4-}, \mathrm{CO}^{3-}, \mathrm{OH}^{-}\right]$and glass systems, which were to be represented as an ideal solution containing associated species.

ULTIMATE OBJECTIVE: High-temperature filtration technology - demonstrate utilization of high-temperature filtration in two Dow Corning applications related to dimethyldichlorosilane production. Thermochemical modeling - (1) predict chemical behavior of molten salts in contact with various materials and use that information to help select corrosion-resistant materials and (2) develop a comprehensive thermochemical model of glass systems that is predictive with regard to stability and liquidus.

TECHNICAL APPROACH: High-temperature filtration technology - the approach of the program is to acquire filter specimens from manufacturers and perform bench-scale compatibility testing. After prioritizing the filter samples based on the testing, full-scale filters will be used in a small process unit at Dow Corning as a proof-of-concept evaluation. Thermochemical modeling - the approach to the thermochemical modeling uses ChemSage (GTT Technologies, RWTH-Aachen, Germany), a commercially available software and database package. Calculations are to be performed starting with simpler systems and working up to multicomponent systems, in the order: binary common-cation, binary common-anion, ternary reciprocal, ternary additive, multicomponent additive, full system.

PROGRESS: High-temperature filtration technology - filter specimens were exposed for $1000-\mathrm{h}$ periods to thermal oxidizer simulated environments. Thermodynamic modeling - phase diagrams were calculated for many of the binary and ternary subsystems in molten smelt and, in the case of the glass, for a pseudoquaternary. To facilitate ongoing evaluation of data and results, two FORTRAN programs were written. 


\section{PROJECT SUMMARY (continued) \\ PROJECT TITLE: Materials For High-Temperature Filtration/Thermochemical Modeling}

ACCOMPLISHMENTS: High-temperature filtration technology - two, 1000-h campaigns for exposing filter materials to a simulated thermal oxidizer environment were completed. Thermodynamics modeling - an extensive literature search for phase diagrams and thermodynamic models of the system of interest was performed. An idealsolution model was successfully applied to the majority of binary systems, several ternary systems, and a quaternary system. Phase diagrams were calculated for 21 of 25 binary systems and 8 of $\sim 40$ ternary systems. Accurate modeling of the quaternary glass composition system $\mathrm{Na}_{2} \mathrm{O}-\mathrm{Al}_{2} \mathrm{O}_{3}-\mathrm{B}_{2} \mathrm{O}_{3}-\mathrm{SiO}_{2}$ was accomplished.

CRITICAL ISSUES: Thermodynamics modeling - data on sulfides are scarce and unreliable. Methods to facilitate the analysis and visualization of computational results are currently not available.

FUTURE PLANS: High-temperature filtration technology - the last 1000-h campaign for exposing filter samples will be completed, and the mechanical properties of the samples will be determined. Thermodynamics modeling - the building of the molten-salt and glass models will continue with calculations on additional ternary and multicomponent systems. Thermodynamic analysis of the solid-salt system in contact with water will be continued, and predictions from the analysis will be compared with experimental results on aqueous solutions over artificial smelts.

POTENTIAL PAYOFF: High-temperature filtration technology - the payoff will be the application of high-temperature filtration to major process systems used by Dow Corning and their suppliers. Thermodynamics modeling - improved corrosion-resistant materials will lead to improved smelt-processing efficiencies. Also, accurate models of glass behavior will aid in minimizing energy for glass melting and in predicting interactions with materials such as refractories.

ESTIMATED ENERGY SAVINGS: High-temperature filtration technology - potential 12 trillion Btu/y by the year 2010 for the high-temperature filter application. Thermodynamics modeling - significant energy savings in heat recovery through the use of black liquor recovery boilers. Minimization of energy use for glass production and reduced losses via prediction of interactions with materials such as refractories. 


\section{SIGNIFICANT ACCOMPLISHMENT}

\section{ADVANCED INDUSTRIAL MATERIALS (AIM) PROGRAM}

\section{Materials for High-Temperature Filtration/Thermochemical Modeling}

ISSUE: Improve the resistance of steel used in black liquor recovery boilers to stress-corrosion cracking under conditions of exposure to molten salts or concentrated aqueous salt solutions.

RESULTS: Phase diagrams were calculated for binary and ternary subsystems with acceptable accuracy when an ideal-solution model was applied. Examples of calculated phase diagrams are shown in Figs. 1 and 2.

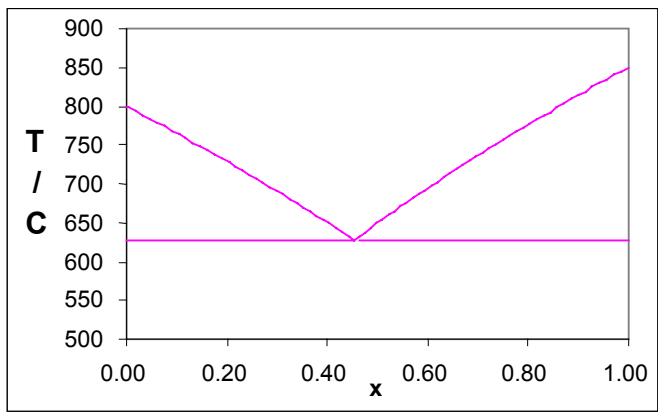

Fig. 1. Phase diagrams for the $\mathrm{NaCl}-\mathrm{Na}_{2} \mathrm{CO}_{3}$ system: optimized diagram from Phase Diagrams for Ceramists (left) and calculated in this work (right).
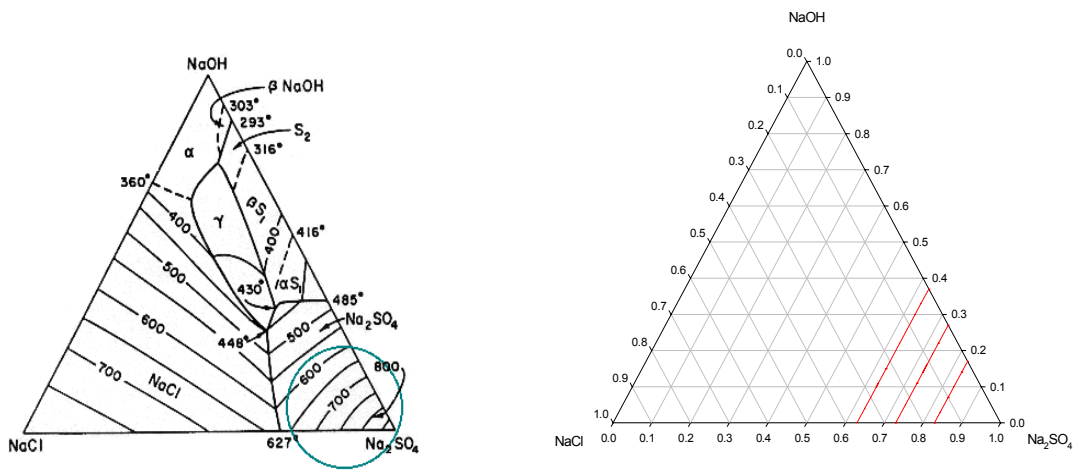

*Fig. 2. Isothermal projections for the $\mathrm{Na}-\mathrm{OH} \mathrm{NaCl}-\mathrm{Na}_{2} \mathrm{CO}_{3}$ system: optimized diagram from the Phase diagrams for ceramists (left) and calculated isotherms at $700^{\circ} \mathrm{C}, 750^{\circ} \mathrm{C}$, and $800^{\circ} \mathrm{C}$ in this work (right).

Research performed at the Oak Ridge National Laboratory, sponsored by the U.S. Department of Energy, Assistant Secretary for Energy Efficiency and Renewable Energy, Office of Industrial Technologies, Advanced Industrial Materials Program, under contract DE-AC05-00OR22725 with UT-Battelle, LLC. 



\section{PROJECT SUMMARY}

\section{ADVANCED INDUSTRIAL MATERIALS (AIM) PROGRAM}

\section{PROJECT TITLE: High-Temperature Facilitated Transport Membranes}

PHASE: FY 1999

COMPLETION DATE:

PERFORMING ORGANIZATION: Los Alamos National Laboratory

PRINCIPAL INVESTIGATOR: David J. Devlin (505-667-9914)

PHASE OBJECTIVE: Development of a membrane and test system.

ULTIMATE OBJECTIVE: Development of a membrane system for the high temperature removal of $\mathrm{CO}_{2}$ from shifted syngas.

TECHNICAL APPROACH: The technical approach involves the use of molten carbonate/oxide salts to react reversibly with $\mathrm{CO}_{2}$ to form carbonates, transport through the membrane, and decompose to oxide on the downstream side.

PROGRESS: We have identified a method for fabricating and testing membranes based on technology developed for molten carbonate fuel cells.

\section{ACCOMPLISHMENTS}

Licenses: None Known Follow-On Products(s): None Industry Workshop: None Technology Transfer or Industrial Interaction: None presently.

CRITICAL ISSUES: Total permeability of $\mathrm{CO}_{2}$ and the separation factors under operating conditions.

FUTURE PLANS: Development and proof of principle of this new type of membrane.

POTENTIAL PAYOFF: While the development of high-temperature, chemically resistant membranes is still in its infancy, it is a technology that, when fully mature, will yield immense returns in both energy conservation and the development of economical new energy sources. Intimately connected to energy conservation is the improvement in efficiency of chemical processes. Of the approximately 30 Quad of energy used by industry each year, improved membranes will save 1 Quad in liquid to vapor separations, 0.68 Quad in natural gas recovery, and 0.36 Quad in oxygen enrichment. Membrane processes can save energy in several ways. Energy-intensive separation processes such as distillation and cryogenics could be replaced by less-intensive membrane processes. Although organic and polymer membranes already are being implemented in various separations applications, inorganic membranes allow processes to be performed at the elevated temperatures and in the environment of most chemical feed streams. 


\section{PROJECT SUMMARY (continued)}

\section{PROJECT TITLE: High-Temperature Facilitated Transport Membranes}

Currently any such procedures require the cooling of the feed stream to near-ambient temperatures and subsequently reheating for further processing.

Hydrogen separation, which drives the fuel cell technology, is integrally connected to membranes. The savings from the implementation of fuel cells for transportation alone are expected to reach as high as 4 billion barrels of oil per day by the year 2030. An additional 2 Quad per year would be saved by implementing fuel cells as energy sources in only $25 \%$ of residential and commercial buildings. The $\mathrm{CO}_{2}$ separated from the combustion products of natural gas or fossil fuels can be used for chemical feedstock via production syngas. The separated hydrogen can be recycled or used as a fuel in a cogeneration plant.

The Department of Energy's Vision 21 concept, "A Pathway to Clean Affordable Energy," focuses on the development of feedstock-flexible energy-plexes, which produce electric power, fuels, and chemicals or combinations of these products. The key enabling technology is gasification, which can process coal, biomass, methane, or waste materials to produce synthesis gas from which electrical power is produced. Hydrogen, methanol, and other petroleum products could be formed from the syngas if profitable. However, in the power plant scenario, synthesis gas is "shifted" to primarily hydrogen and carbon dioxide (via the water-gas shift reaction), the raw feedstocks are "decarbonized" through $\mathrm{CO}_{2}$ removal, and the remaining gas is fed to a combustion turbine and/or a hightemperature fuel cell. Thus an effective and competitive means of separating the carbon dioxide is essential to meeting overall plant efficiency objectives. It is best to make such a separation of $\mathrm{CO}_{2}$ prior to use in the fuel cell and is best accomplished at high temperatures. Cooling the process stream to perform the separation and reheating to $900^{\circ} \mathrm{C}$ to feed the cell would make the process economically unattractive. The associated costs for gas/solid adsorption and cryogenic fractionation separations are over the $50 \%$ of the coal heating value. Separation of hydrogen from $\mathrm{CO}_{2}$ at high temperatures and pressures (i.e., $600^{\circ}$ to $900^{\circ} \mathrm{C}$ and up to $600 \mathrm{psi}$ ) with a membrane system is currently not possible.

ESTIMATED ENERGY SAVINGS: Hydrogen separation, which drives the fuel-cell technology, is integrally connected to membranes. The savings from the implementation of fuel cells for transportation alone are expected to reach as high as 4 billion barrels of oil per day by the year 2030. An additional 2 Quad per year would be saved by implementing fuel cells as energy sources in only $25 \%$ of residential and commercial buildings. 


\section{SIGNIFICANT ACCOMPLISHMENT}

\section{ADVANCED INDUSTRIAL MATERIALS (AIM) PROGRAM}

\section{High-Temperature Facilitated Transport Membranes}

ISSUE: The purpose of this project is to develop and evaluate a new high-temperature membrane for the separation of carbon dioxide from hydrogen. The primary application is the removal of $\mathrm{CO}_{2}$ from shifted syngas streams prior to use in gas turbines or hightemperature fuel cells. This could have a significant impact on energy efficiency, waste reduction, and productivity in power plants, the chemical processing industry, and cogeneration facilities. In addition, should future regulations motivate or require carbon dioxide sequestration, a viable carbon dioxide separation technique will be essential in implementing an economically competitive sequestration technology. The system proposed represents a novel approach to high-temperature separations and is based on a molten salt contained within a porous matrix and functioning as a facilitated transport membrane.

RESULTS: We have identified a method for fabricating and testing membranes based on technology developed for molten carbonate fuel cells. The technical approach involves the use of molten carbonate/oxide salts to react reversible with $\mathrm{CO}_{2}$ to form carbonates, transport through the membrane, and decompose to oxide on the downstream side.

ENERGY EFFICIENCY: Hydrogen separation, which drives the fuel-cell technology, is integrally connected to membranes. The savings from the implementation of fuel cells for transportation alone are expected to reach as high as 4 billion barrels of oil per day by the year 2030. An additional 2 Quad per year would be saved by implementing fuel cells as energy sources in only $25 \%$ of residential and commercial buildings. 



\section{PROJECT SUMMARY}

\section{ADVANCED INDUSTRIAL MATERIALS (AIM) PROGRAM}

\section{PROJECT TITLE: Membrane Systems for Energy-Efficient Separation of Light Gases}

PHASE: FY 1999

\section{COMPLETION DATE:}

PERFORMING ORGANIZATION: Los Alamos National Laboratory

PRINCIPAL INVESTIGATOR: David J. Devlin (505-667-9914)

PHASE OBJECTIVE: Development of a process based on vapor-deposition techniques for the fabrication of membrane systems for light-gas separation.

ULTIMATE OBJECTIVE: Development of a membrane system suitable for operation in a pilot-scale system for the separation of $\mathrm{C} 1$ to $\mathrm{C} 4$ hydrocarbons from hydrogen.

TECHNICAL APPROACH: The technical approach involves the use of vapor deposition techniques to tailor pore size and shape in porous substrates. The pore properties will be engineered to effect capillary condensation of hydrocarbons near ambient temperatures and pressures less than $250 \mathrm{psig}$.

PROGRESS: A method for developing carbon pores for capillary condensation of hydrocarbons has been devised. Experiments demonstrate the feasibility of oblique-angle vapor deposition as a means producing the desired pore structure. Separation of hydrocarbon gas mixtures with these membranes has been demonstrated.

\section{ACCOMPLISHMENTS:}

Licenses: None Known Follow-On Products(s): None Industry Workshop: None

Technology Transfer or Industrial Interaction: This effort is expected to continue in 2000 as a joint research effort with BP Amoco Chemical Company. Amoco will develop characterization capabilities and design criteria for the membrane systems. With their guidance we will develop the materials and processing for the fabrication of these of membranes. Amoco's goal is a materials system capable of scaling for use in a pilot-plant system.

CRITICAL ISSUES: The precise control of pore structure in membrane materials.

FUTURE PLANS: Development of materials by vapor-deposition techniques with engineered pore size and shape. Characterization and performance testing of developed materials by Amoco Olefins R\&D. 


\section{PROJECT SUMMARY (continued)}

\section{PROJECT TITLE: Membrane Systems for Energy Efficient Separation of Light Gases}

POTENTIAL PAYOFF: There are important benefits that will result from the success of the proposed CRADA effort. The U.S. hydrocarbon industry has experienced a loss in competitiveness over the last decade that has resulted in the loss of nearly 500,000 jobs and has severely affected the U.S. balance of trade. Improvements in hydrocarbon lightgas separation processes represent the largest area for potential cost reductions for the entire hydrocarbon industry, which includes natural gas processing, oil refining, and petrochemicals. For example, new grass-roots olefins units cost upward of \$750 million; the separation section accounts for approximately $75 \%$ of this capital investment. Because of the high capital costs and market competitiveness, U.S. olefin producers have relied on debottlenecking of existing units to meet capacity increases required to maintain market share. Shortly, these activities will not be feasible because of compressor-train capacity limitations. Non-cryogenic breakthrough technologies for separating light-gas by-products from olefinic mixtures could lead to inexpensive capacity increases of $50 \%$; this would significantly reduce manufacturing costs and promote industry growth. Also, the development of energy-efficient gas-separation processes will have a positive impact on the environment. Lower energy consumption translates into less fuel burning to generate power, resulting in a significant reduction in flue-gas pollutants such as hazardous nitrogen and carbon oxides. Reducing pollutants is critical in the major industrial regions that have become nonattainment areas based on the National Ambient Air Quality Standards. Growth and job creation in these regions is dependent on reducing these emissions. Lower energy consumption would create the opportunity to expand and still meet the environmental guidelines while lessening U.S. dependence on energy imports.

ESTIMATED ENERGY SAVINGS: Initial economic analyses have shown that the commercialization of this novel separation concept could result in an energy reduction potential of 5 trillion Btu per year for an olefins complex: this corresponds to a potential annual savings of nearly $\$ 8$ million. 


\section{SIGNIFICANT ACCOMPLISHMENT}

\section{ADVANCED INDUSTRIAL MATERIALS (AIM) PROGRAM}

\section{Membrane Systems for Energy-Efficient Separation of Light Gases}

ISSUE: Ethylene and propylene are two of the largest commodity chemicals in the United States and are major building blocks for the petrochemicals industry. These olefins are separated currently by cryogenic distillation, which demands extremely low temperatures and high pressures. Over 75 billion pounds of ethylene and propylene are distilled annually in the United States at an estimated energy requirement of 400 trillion Btu. Nondomestic olefin producers are rapidly constructing state-of-the-art plants. These energy-efficient plants are competing with an aging U.S. olefins industry in which $75 \%$ of the olefins producers are practicing technology that is more than 20 years old. New separation opportunities are therefore needed to continually reduce energy consumption and remain competitive.

RESULTS: We have shown that oblique-angle vapor-deposition techniques can be used to produce thin films with pores in the desired range of 4 to $5 \mathrm{~nm}$. We have tested a number of systems of interest consisting of $\mathrm{C} 1$ through $\mathrm{C} 4$ hydrocarbons with nitrogen and hydrogen. Good separation factors along with permeability have been obtained.

ENERGY EFFICIENCY: Initial economic analyses have shown that the commercialization of this novel separation concept could result in an energy reduction potential of 5 trillion Btu per year. 



\title{
PROJECT SUMMARY
}

\section{ADVANCED INDUSTRIAL MATERIALS (AIM) PROGRAM}

\author{
PROJECT TITLE: New Method for Synthesis of Metal Carbides, Nitrides, and \\ Carbonitrides
}

PHASE: FY 1999

COMPLETION DATE:

PERFORMING ORGANIZATION: Southern Illinois University at Carbondale

PRINCIPAL INVESTIGATOR: Rasit Koc (618-453-7005)

PHASE OBJECTIVE: To promote the transfer of the technology developed under the AIM program. The technology deals with a new process for producing high-purity, submicron, nonagglomerated metal-carbide $(\mathrm{SiC}, \mathrm{TiC}, \mathrm{WC})$, metal-nitride $\left(\mathrm{TiN}, \mathrm{Si}_{3} \mathrm{~N}_{4}\right)$ and metal-boride $\left(\mathrm{TiB}_{2}\right)$ powders.

ULTIMATE OBJECTIVE: To develop a novel synthesis method for producing highquality, low-cost powders of metal carbide, metal nitride and metal boride using carboncoated precursors. To demonstrate the advantages of the process and understand the formation of submicron powders from carbon-coated precursors. To perform initial investigation on the sintering behavior of these powders.

TECHNICAL APPROACH: The process developed in this project utilizes a carbothermic reduction reaction of novel carbon-coated precursors that has potential as a low-cost powder-synthesis route. It minimizes kinetic barriers by improving the way carbon is introduced to the reactants. The process consists of two steps. The first step is the coating of interested metal-containing powders with carbon by decomposing a hydrocarbon gas at temperatures of 400 to $600^{\circ} \mathrm{C}$. The second step involves the formation of metal-carbide, metal-nitride, and metal-boride powders by promoting the carbothermal reduction of the carbon-coated metal-containing particles in an inert atmosphere at temperatures of 1200 to $1600^{\circ} \mathrm{C}$. This way of increasing contact area between reactants results in a more complete reaction and a purer product at comparatively lower temperatures. The complete separation of the metal-containing (oxides) particles by coated carbon and low-temperature processing results in products with less particle agglomeration and uniform particle size. 


\section{PROJECT SUMMARY (continued)}

PROJECT TITLE: New Method for Synthesis of Metal Carbides, Nitrides, and Carbonitrides

PROGRESS: The carbon-coating method developed for production of WC powders from carbon-coated $\mathrm{WO}_{3}$ powders was investigated using high temperature TGA, DSC, $\mathrm{XRD}$, and TEM. Comparison between use of a standard mixture and a partially coated/mixed precursor was evaluated. Additionally, formation of tungsten powder was achieved using the coated precursor without further addition of carbon. Further, synthesis of submicron TiC powder was accomplished at a shorter reaction time, $2 \mathrm{~h}$, than previously used.

Patent: U.S. 5,417,952

Books: None
Publications: 10

Presentations: 10

\section{Proceedings: 4}

Awards: 2

\section{ACCOMPLISHMENTS:}

Awards: R. Koc, Sigma Xi Kaplan Research Award, 1998.

\section{Technology Transfer or Industrial Interaction:}

ART has licensed the SiC patent to produce SiC powders. Greenleaf Inc. is interested in licensing of TiC patent.

CRITICAL ISSUES: Applicability of the process to synthesize other metal carbides, nitrides, and borides with high quality and low cost.

FUTURE PLANS: Investigate the formation of submicron powders from carbon-coated precursors using a high-temperature TGA-DTA/DSC unit. Characterize the resulting powders and provide information about their sinterability.

POTENTIAL PAYOFF: Acquisition of a new process for the production of nonoxide advanced ceramic powders that will provide a supply of low-cost high-quality (highpurity, fine-particle size) powders. The low cost of powders will have a major impact on the cost of finished products, thereby expanding current markets.

ESTIMATED ENERGY SAVING: This technology will improve energy efficiency when compared to the conventional processes because it does not require high-reaction temperatures nor the long reaction times for production of these powders. 


\section{SIGNIFICANT ACCOMPLISHMENT}

\section{ADVANCED INDUSTRIAL MATERIALS (AIM) PROGRAM}

\section{PROJECT TITLE: New Method for Synthesis of Metal Carbides, Nitrides, and Borides}

ISSUE: The formation of $\mathrm{WC}$ and $\mathrm{W}$ using the carbon-coated $\mathrm{WO}_{3}$ precursor was investigated. The use of TGA/DSC and XRD was instrumental in this research. Also, production of $\mathrm{TiC}$ powder produced at a short processing time was investigated.

RESULTS: The activation energy of $\mathrm{W}$ formation was calculated as $626 \pm 18.2 \mathrm{~kJ} / \mathrm{mol}$. Also, DSC demonstrated the superiority of using coated precursors over mixed precursors. The coated precursor experienced greater conversion than the mixed samples at all given temperatures. TiC powder was produced in flowing Ar at a reaction time of only $2 \mathrm{~h}$. The resulting powders were submicron and nonagglomerated, with a narrow size distribution.

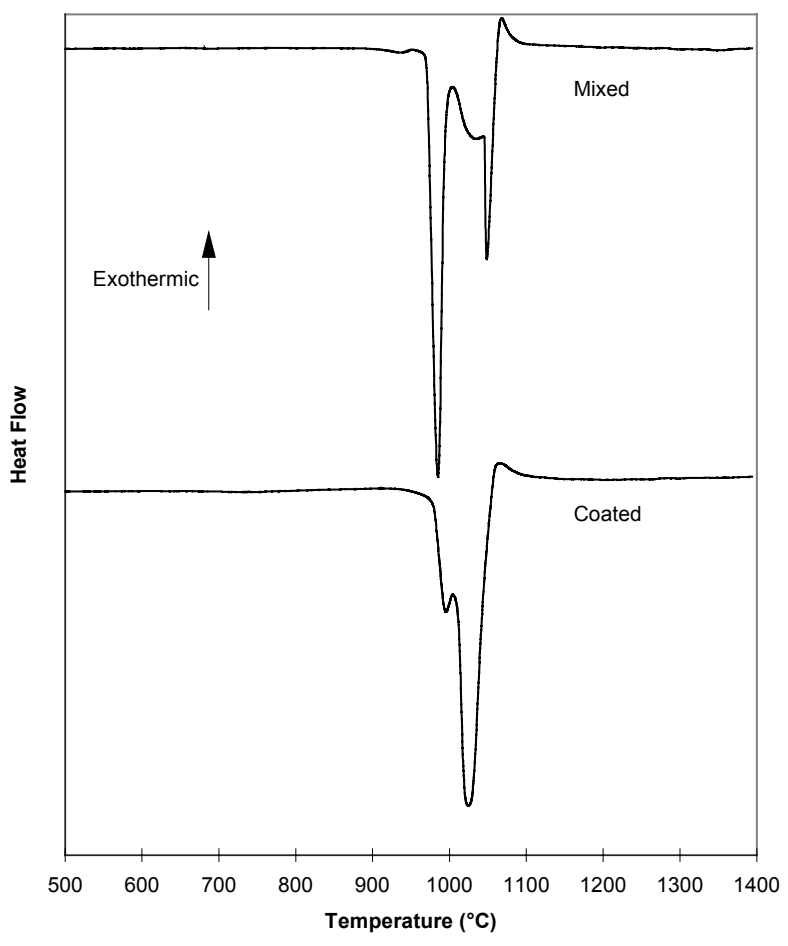

Fig. 1. DSC curves for WC formation.

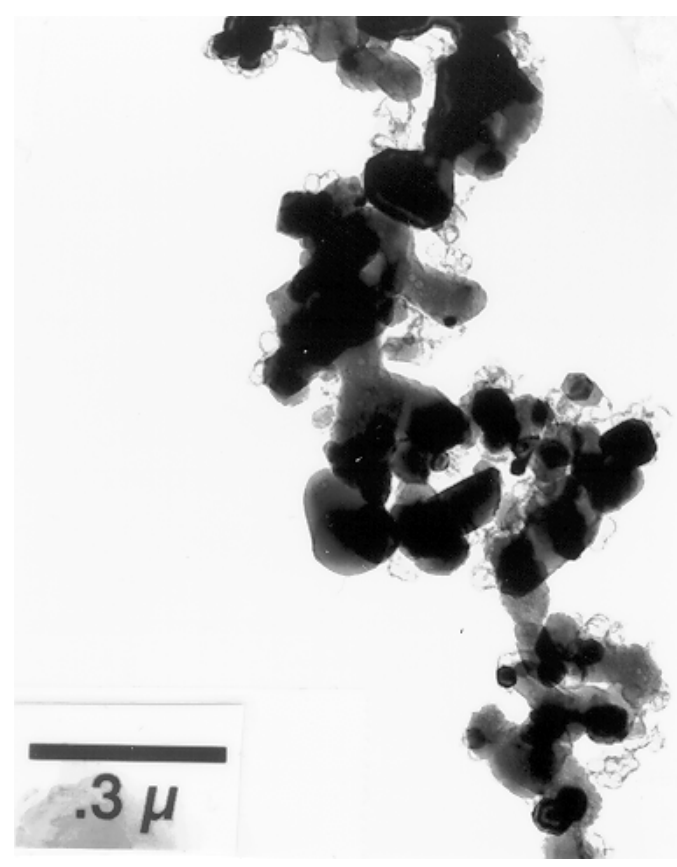

Fig. 2. TEM of $\mathrm{TiC}$ from $2 \mathrm{~h}$ at $1500^{\circ} \mathrm{C}$.

ENERGY EFFICIENCY: This technology will improve energy efficiency because it does not require high-reaction temperatures for production of these superior powders.

Research sponsored by the U.S. Department of Energy, Assistant Secretary for Energy Efficiency and Renewable Energy, Office of Industrial Technologies, Advanced Industrial Materials Program, under contract DE-AC05-00OR22725 with UT-Battelle, LLC. 



\section{PROJECT SUMMARY}

\section{ADVANCED INDUSTRIAL MATERIALS (AIM) PROGRAM}

\section{PROJECT TITLE: Synthesis and Processing of Composites by Reactive Metal Penetration}

PHASE: FY 1999

COMPLETION DATE:

PERFORMING ORGANIZATION(S): Sandia National Laboratories (SNL); Subcontractors: University of Missouri at Rolla (Rolla), New Mexico Institute of Mining and Technology (NMIMT), and SRI International (SRI)

PRINCIPAL INVESTIGATORS: Ronald E. Loehman/SNL (505-272-7601); Subcontractor PIs: Rolla: William G. Fahrenholtz (573-341-6343), NMIMT: Ping Lu (505-835-5731), and SRI: Sylvia M. Johnson (650-859-4277)

PHASE OBJECTIVE: To identify compositions favorable for making composites and coatings by in situ reactive methods, to understand the mechanism(s) by which they are formed, and to apply that understanding to improving ceramic refractories.

ULTIMATE OBJECTIVE: To learn to make high-quality composites and composite coatings economically, and to apply the results to problems of interest to industry.

TECHNICAL APPROACH: Composites are made by reacting molten metals with ceramics under controlled conditions. Coatings are made from organometallic polymers filled with ceramic and metal powders that are converted to adherent films. Mechanistic process models are developed from kinetic, microstructural, and phase diagram data combined with thermodynamic calculations. We use those results to make specimens for testing and evaluation.

PROGRESS: We previously discovered how to use variations in heating rate to control reaction rates in composite formation. We have used this technique to prepare dense, high-strength composites with compositions that were previously inaccessible, for example $\mathrm{Al}_{2} \mathrm{O}_{3}-\mathrm{MoSi}_{2}, \mathrm{Al}_{2} \mathrm{O}_{3}-\mathrm{Ni}$, and $\mathrm{Al}_{2} \mathrm{O}_{3}-\mathrm{Nb}$. These composites exhibited excellent combinations of strength and toughness $\left(\mathrm{Al}_{2} \mathrm{O}_{3}-\mathrm{Ni}\right)$, strength and hardness $\left(\mathrm{Al}_{2} \mathrm{O}_{3}-\mathrm{Nb}\right)$, and high-temperature strength $\left(\mathrm{Al}_{2} \mathrm{O}_{3}-\mathrm{MoSi}_{2}\right)$. We studied composite coating formulations for thermal barrier applications. Coatings of $\mathrm{Al} / \mathrm{Al}_{2} \mathrm{O}_{3}, \mathrm{Zn} / \mathrm{SiO}_{2}$, and $\mathrm{TiO}_{2} / \mathrm{Al}_{2} \mathrm{O}_{3}$ combined excellent corrosion resistance and hardness. Coating chemistry was varied to cure at room temperature to improve surface adhesion.

Patents: 1

Books: None
Publications: 4

Master's Theses: 1
Proceedings: 2

Presentations: 17 


\section{PROJECT SUMMARY (continued)}

\section{PROJECT TITLE: Synthesis and Processing of Composites by Reactive Metal Penetration}

Technology Transfer or Industrial Interaction: We have initiated collaborations with National Refractories and Minerals Corp. of Livermore, California, and BFD, Inc., of Columbus, Ohio. Sandia and National have agreed to collaborate to develop improved refractories for the aluminum industry. Sandia is collaborating with BFD to apply our understanding of reaction mechanisms to improve processing of BFD's composites. SRI has established evaluation projects with several companies to assess the applicability of their coating technology for commercial uses.

CRITICAL ISSUES: Exceptional properties, high reliability, and acceptable cost are critical requirements for any new material. Learning how to control wetting and reactivity of ceramics by molten metals is a prerequisite for developing reliable materials by reactive techniques. Understanding reaction mechanisms is necessary for development of a wider range of composites, such as $\mathrm{MoSi}_{2}-\mathrm{Al}_{2} \mathrm{O}_{3}, \mathrm{Ni}-\mathrm{Al}_{2} \mathrm{O}_{3}$, and $\mathrm{Nb}-\mathrm{Al}_{2} \mathrm{O}_{3}$. This understanding also is important for improving refractories for the metal-processing industry.

FUTURE PLANS: A major part of the FY 2000 effort will be devoted to improving ceramic refractories in the CRADA work with National Refractories. We will continue developing the novel ceramic composites we have been studying, such as those containing $\mathrm{Ni}$ and $\mathrm{Nb}$ that possess such outstanding properties. SRI will continue improving processing behavior of its coatings, they will determine thermal barrier coating performance at high temperatures.

POTENTIAL PAYOFF: Reactively formed composites may have many applications because of their outstanding properties. Improved refractories for aluminum processing would lead to large increases in process efficiency. Near-net-shape fabrication of parts has the additional advantage that costly and energy-intensive grinding and machining operations are significantly reduced, and the waste generated from such finishing operations is minimized.

OTHER SOURCES: Cost sharing primarily has been in the form of continuing collaborations that are maintained at no cost to the project. National Refractories has prepared samples and provided analysis as their contribution to our collaboration. W. G. Fahrenholtz, now at University of Missouri at Rolla, is supporting the collaboration using start-up funds from the university. A. P. Tomsia and his associate, Eduardo Saiz, use internal funding from Lawrence Berkeley National Laboratory to support their contributions to the collaboration. Graduate and undergraduate students who work on the project with support from their home institutions (University of Washington at Rolla) represent an in-kind level of $\sim \$ 50,000$. 


\section{SIGNIFICANT ACCOMPLISHMENT}

\section{ADVANCED INDUSTRIAL MATERIALS (AIM) PROGRAM}

\section{New Ceramic-Metal Composites with Exceptional Mechanical Properties}

ISSUE: Many new applications for structural materials require parts that have significant increases in strength, toughness, stiffness, and hardness and with lower density as compared with those of conventionally available metal alloys. One promising approach is to use composite materials that have optimized combinations of properties that are not achievable with single-phase materials.

RESULTS: $\mathrm{Al}_{2} \mathrm{O}_{3}-\mathrm{Ni}$ composites with $\sim 35$ vol $\% \mathrm{Ni}$ were prepared by reactive hot pressing. The composite strength was over $600 \mathrm{MPa}$, and the fracture toughness was in excess of $12 \mathrm{MPa} \cdot \mathrm{m}^{1 / 2}$, which are significantly higher than previously reported for other $\mathrm{Al}_{2} \mathrm{O}_{3}-\mathrm{Ni}$ composites. $\mathrm{SEM}$ analysis revealed a co-continuous microstructure with $\mathrm{Ni}$ ligament sizes on the order of $5 \mu \mathrm{m}$. The paths of indentation cracks indicated strong bonding at the $\mathrm{Ni}-\mathrm{Al}_{2} \mathrm{O}_{3}$ interface. Good interfacial bonding allowed the Ni ligaments to bridge cracks, increasing the toughness of the composite. A composite of $\mathrm{Al}_{2} \mathrm{O}_{3}$ and $30 \mathrm{Vol} \% \mathrm{Nb}$ had a high strength of $530 \mathrm{MPa}$, a hardness of $15 \mathrm{GPa}$, and a toughness of $6.2 \mathrm{MPa} \cdot \mathrm{m}^{1 / 2}$. Properties of these composites compare favorably to some of the best structural materials.

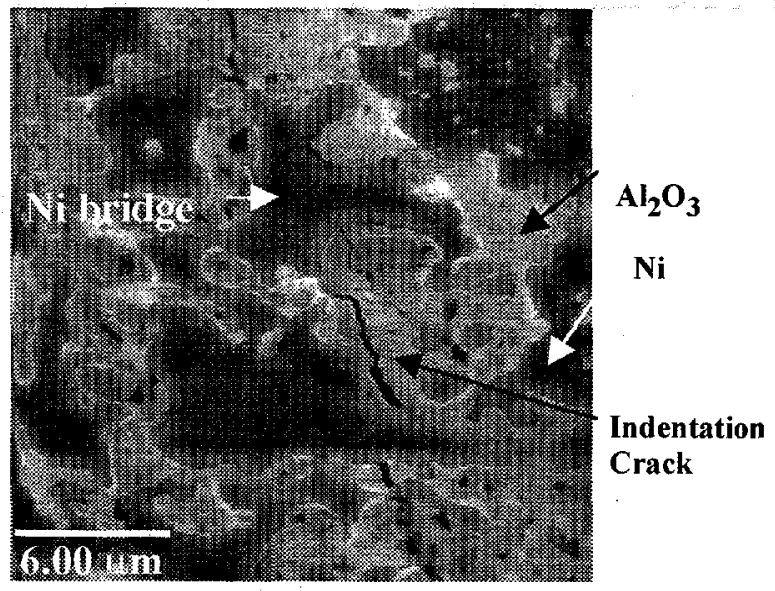

Fig. 1. $\mathrm{Ni}-\mathrm{Al}_{2} \mathrm{O}_{3}$ composite showing bridging of an indentation crack. This explains the exceptional toughness.

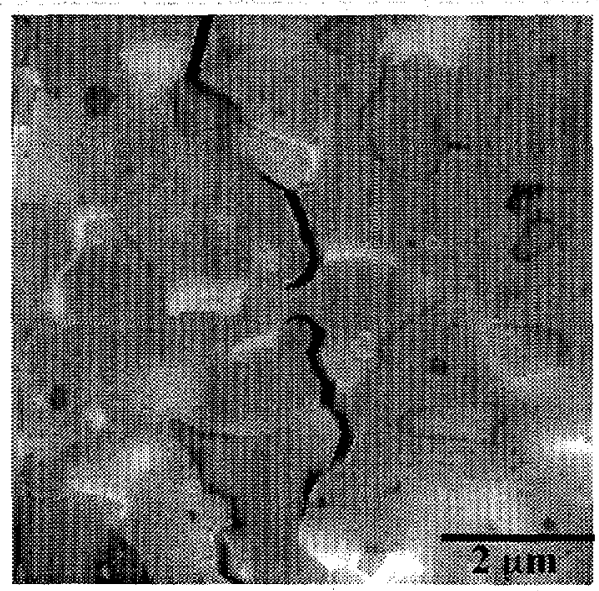

Fig. 2. $\mathrm{Nb}-\mathrm{Al}_{2} \mathrm{O}_{3}$ composite that exhibits high strength and hardness. 



\section{ADVANCED \\ INTERMETALLICS/METALS AND COMPOSITES}





\title{
PROJECT SUMMARY
}

\section{ADVANCED INDUSTRIAL MATERIALS (AIM) PROGRAM}

\author{
PROJECT TITLE: Advanced Ordered Intermetallic Alloy Development
}

PHASE: FY 1999

COMPLETION DATE:

PERFORMING ORGANIZATION: Oak Ridge National Laboratory (ORNL)

PRINCIPAL INVESTIGATORS: C. T. Liu (865-574-4459) and J. H. Zhu (865-574-4343)

PHASE OBJECTIVE: To develop nickel silicide alloys that exhibit good corrosion resistance, improved fabricability, decent low- and high-temperature ductility and strength, and superior creep resistance for chemical and other vision industrial use.

ULTIMATE OBJECTIVE: (1) to develop low-density, high-strength, corrosionresistant intermetallic alloys for structural applications in chemical and other vision industry systems.

TECHNICAL APPROACH: Both macroalloying and microalloying approaches are employed to improve metallurgical and mechanical properties of nickel silicide intermetallic alloys. The selection of alloying additions will be based on physical metallurgy principles, structural maps, and empirical correlation. Emphasis will be placed on improving fabricability, weldability, ductility, and toughness as well as strength and corrosion resistance at ambient and elevated temperatures through composition adjustment, material processing, and structural control.

PROGRESS: A number of new alloys based on $\mathrm{Ni}_{3} \mathrm{Si}$ were produced, fabricated, and evaluated at room and elevated temperatures. Beneficial elements have been discovered to increase the intermediate-temperature ductility and fabricability of the alloys. Preoxidation to form adherent oxide layers and thermomechanical processing to tailor grain morphology have also been found effective in increasing the ductility of the nickel silicide alloys. The nickel silicide intermetallic alloys developed also have excellent weldability.

\section{Invention Disclosures: 1 Publications: 1 Proceedings: None Presentations: 3}

\section{ACCOMPLISHMENTS:}

Licenses: Discussions with several U.S. industries for potential technology transfer.

Known Follow-On Product: Anticipated use in various industries. 


\section{PROJECT SUMMARY (continued)}

\section{PROJECT TITLE: Advanced Ordered Intermetallic Alloy Development}

OTHER SUCCESSFUL TECHNOLOGY TRANSFER ACTIVITIES AS EVIDENCE OF INDUSTRY INTEREST: At the DOE Workshop on Ordered Intermetallic Alloys held in Atlanta, Georgia, in June 1996, Cummins Engine Company and United Defense both expressed interest in nickel silicides for petrochemical and chemical industries. Haynes International is interested in $\mathrm{Ni}_{3} \mathrm{Si}$ alloys with improved ductility and fabricability at elevated temperatures.

CRITICAL ISSUES: (1) To alleviate oxygen-induced environmental embrittlement at intermediate temperature and improve hot fabricability of nickel silicide alloys and (2) to improve the creep resistance of nickel silicide alloys.

FUTURE PLANS: (1) To optimize alloy composition and processing route of $\mathrm{Ni}_{3} \mathrm{Si}$ alloys with excellent hot fabricability, weldability, corrosion resistance, tensile ductility, and creep resistance at elevated temperatures and (2) to initiate technology transfer of nickel silicide alloys with enhanced properties.

POTENTIAL PAYOFF: There are two major problems with intermetallic alloys; poor ductility at ambient and intermediate temperatures and limited corrosion and creep resistance at elevated temperatures. If these problems can be overcome, it will result in the development of a whole new class of ordered intermetallic alloys that are superior to those of existing superalloys. 


\section{SIGNIFICANT ACCOMPLISHMENT}

\section{ADVANCED INDUSTRIAL MATERIALS (AIM) PROGRAM}

\section{Alloy Design of Corrosion-Resistant Nickel Silicide Alloys}

PROBLEM: Nickel silicide, $\mathrm{Ni}_{3} \mathrm{Si}$, offers good acid resistance and has the potential to be used in a number of chemical industrial systems at elevated temperatures. The major concerns for structural applications include limited ambient- and intermediatetemperature ductility, poor warm and hot fabricability, and insufficient creep resistance. The current development effort has been focused on improving both mechanical and metallurgical properties of $\mathrm{Ni}_{3} \mathrm{Si}$ alloys by alloy design.

RESULTS: The intermediate temperature ductility of nickel silicide alloys can be substantially improved by alloying elements, preoxidation, and thermomechanical processing (see Table 1). Furthermore, the nickel silicide alloys developed at ORNL also have excellent weldability (see Fig. 1).

Table 1. Effect of Alloying Addition, Preoxidation, and Thermomechanical Processing (TMP) on the Ductiltiy of NSI-16 at $600^{\circ} \mathrm{C}$ in Air

\begin{tabular}{|c|c|c|c|c|}
\hline Condition & Final Heat Treatment & Elongation, \% & YS, MPa & UTS, MPa \\
\hline NSI-8 & $3 \mathrm{~d} @ 950^{\circ} \mathrm{C}$ & 1.6 & 655 & 655 \\
\hline NSI-16 & $3 \mathrm{~d} @ 950^{\circ} \mathrm{C}$ & 6.7 & 722.6 & 1026 \\
\hline NSI-20 & $3 \mathrm{~d} @ 950^{\circ} \mathrm{C}$ & 10 & 715 & 1091 \\
\hline Preoxidation & $4 \mathrm{~h} @ 700^{\circ} \mathrm{C}$ & 12.1 & 734 & 1041 \\
\hline TMP & $1 \mathrm{~h} @ 800^{\circ} \mathrm{C}$ & 13.6 & 1083 & 1225 \\
\hline
\end{tabular}
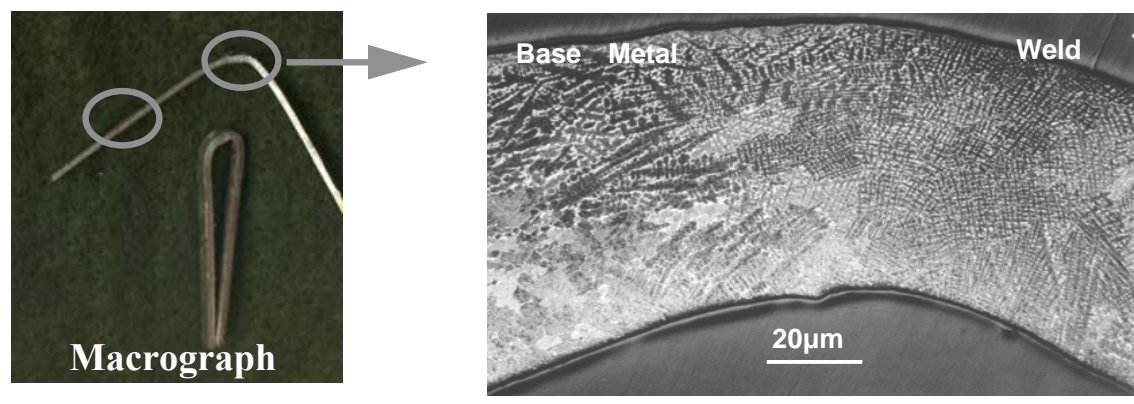

Fig. 1. Welds of NSI-16 are bendable.

SIGNIFICANCE - FOR ENERGY EFFICIENCY: The development of ductile, lightweight, corrosion- and creep-resistant $\mathrm{Ni}_{3} \mathrm{Si}$ and other intermetallic alloys for structural applications is expected to substantially improve the performance of chemical and other vision-industry energy systems. All of these will result in a substantial energy saving for these systems. 



\title{
PROJECT SUMMARY
}

\section{ADVANCED INDUSTRIAL MATERIALS (AIM) PROGRAM}

\author{
PROJECT TITLE: Advanced Iron- and Nickel-Based Alloys
}

PHASE: FY 1999

COMPLETION DATE:

PERFORMING ORGANIZATION: Oak Ridge National Laboratory (ORNL)

PRINCIPAL INVESTIGATORS: P. J. Maziasz (865-574-5082) and R. W. Swindeman (865-574-5108)

PHASE OBJECTIVE: Determine mechanistic causes for failure or limitations for current Fe-Cr-Ni alloys used by chemical/petrochemical industry, develop modified alloys or processing that improves properties for immediate application. Develop comparable alloys that can be used with iron-aluminides to produce bimetallic tubing with "super" coking/carburization resistance.

ULTIMATE OBJECTIVE: Provide furnace tubing or supporting structural materials with better corrosion/carburization/coking resistance and creep-resistance that or more reliable or cost-effective relative to current alloys used for ethylene or styrene production.

TECHNICAL APPROACH: The approach is to (1) analyze (e.g., mechanical properties, microstructure) critical components of current alloys with long-term exposure in current chemical processing industry to understand mechanisms responsible for properties degradation and determine solutions for improved performance and reliability, (2) develop modified alloys with improved creep strength and rupture life and alloys compatible with iron-aluminides as bi-metallic tubing, and (3) develop test components for industrial evaluation

PROGRESS: "Super" catalytic coking resistance of FeAl has been confirmed by a second round of laboratory tests run by Dow Chemical. Efforts to produce bi-metallic tubing of HP micro-alloyed (centrifugally cast) or alloy 803 (wrought) are under way. Analysis of wrought alloy $800 \mathrm{H}$ exit piping $\left(635^{\circ}\right.$ to $810^{\circ} \mathrm{C}, 73,500$ to $\left.90,000 \mathrm{~h}\right)$ and cast $\mathrm{HP}$ micro-alloyed steam superheater tubing $\left(927^{\circ}\right.$ to $\left.1066^{\circ} \mathrm{C}, 105,000 \mathrm{~h}\right)$ from a styrene furnace built by ABB Lummus Global and operated by NOVA Chemical is in progress or completed. Analysis of similar advanced alloy $800 \mathrm{HT}$ exit piping that failed after relatively short service is also under way.
Patents: None
Publications: 1
Proceedings: None
Books: None
Presentations: 1
Awards: None

ACCOMPLISHMENTS: Testing of FeAl by Dow Chemical for coking resistance in ethylene furnace applications was completed. A project was completed with Pennsylvania State University, ABB Lummus Global and NOVA Chemical on alloy $800 \mathrm{H}$ styrene furnace exit piping, and partnership with $\mathrm{ABB}$ and NOVA has continued and expanded. 


\section{PROJECT SUMMARY (continued)}

PROJECT TITLE: Advanced Iron- and Nickel-Based Alloys

Licenses: None Known Follow-On Products: None Industry Workshop: None

Technology Transfer or Industrial Interaction: Project is based on industrial partnership.

CRITICAL ISSUES: None.

FUTURE PLANS: Include technical, technology transfer or industrial interactions.

POTENTIAL PAYOFF: None.

ESTIMATED ENERGY SAVINGS: None. 


\section{SIGNIFICANT ACCOMPLISHMENT}

\section{ADVANCED INDUSTRIAL MATERIALS (AIM) PROGRAM}

\section{Cast FeAl Alloys Have Outstanding Resistance to Catalytic Coking for Ethylene Cracking Applications}

ISSUE: FeAl iron-aluminides have outstanding oxidation, sulfidation, and carburization resistance at $1000^{\circ} \mathrm{C}$ and above due to protective $\mathrm{Al}_{2} \mathrm{O}_{3}$ scale formation. However, do such materials respond to the severe coking deposits that build up during ethylene cracking, which require decoking and carburize and waste the metal tubes beneath such deposits.

RESULTS: New cast FeAl alloys (Fe: 36 to 40 at. \% Al), designed for improved hightemperature corrosion and mechanical properties behavior, were subjected to severe laboratory tests by Dow Chemical that simulate coking and decoking during service in an ethylene cracking furnace. Multiple runs (5) were conducted on an initial set of FeAl specimens at 1000 and $1050^{\circ} \mathrm{C}$, tests which showed for the first time almost complete resistance to catalytic coking relative to nickel aluminides or the best commercial cast FeCr-Ni (HP-modified) alloys. A second round of testing on new, different heats of cast FeAl basically confirmed the initial results, a very significant accomplishment.

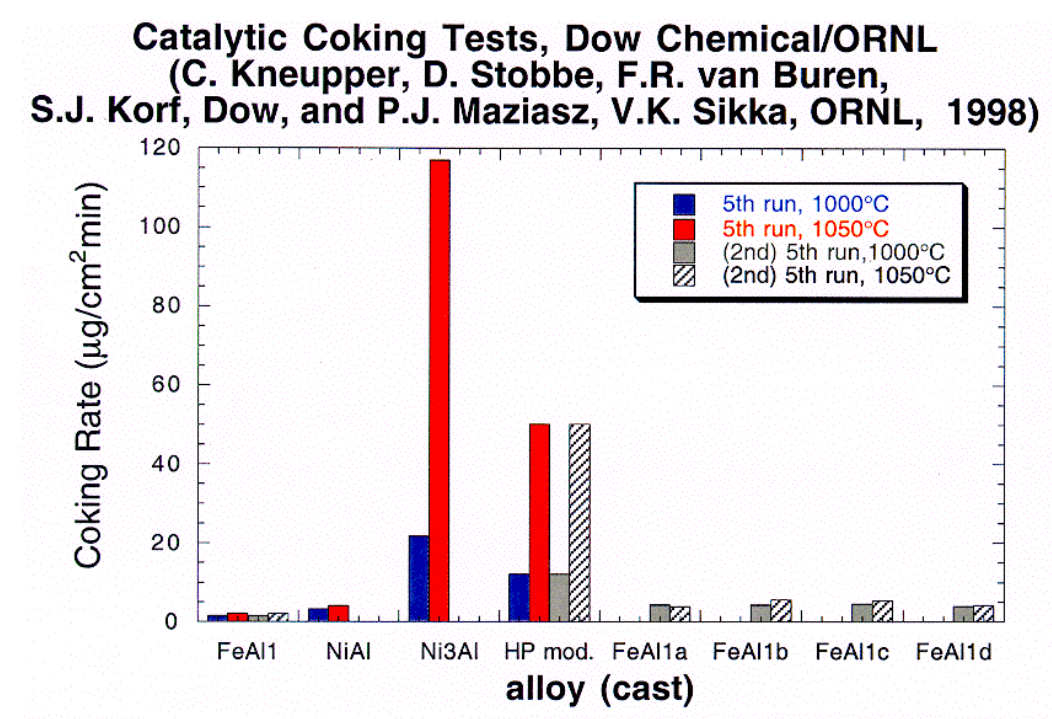

ENERGY EFFICIENCY: "Super" corrosion-resistant FeAl may be able to protect current materials and prevent the severe metal wastage that requires replacement of FeCr-Ni stainless alloys in ethylene cracking applications today. Energy efficiencies will be achieved by (1) increasing the thermal efficiency of tubes during normal ethylene operations, (2) decreasing or eliminating de-coking operations, (3) decreasing downtime, and (4) using longer-lasting tube materials. Reducing the necessity of decoking is also environmentally beneficial with regard to $\mathrm{CO}_{2}$ and $\mathrm{CO}$ production.

Research sponsored by the U.S. Department of Energy, Assistant Secretary for Energy Efficiency and Renewable Energy, Office of Industrial Technologies, Advanced Industrial Materials Program, under contract DE-AC05-00OR22725 with UT-Battelle, LLC. 



\section{PROJECT SUMMARY}

\section{ADVANCED INDUSTRIAL MATERIALS (AIM) PROGRAM}

\section{PROJECT TITLE: High-Density Infrared Processing of Materials}

PHASE: FY 1999

COMPLETION DATE:

PERFORMING ORGANIZATION: Oak Ridge National Laboratory (ORNL)

PRINCIPAL INVESTIGATORS: C. A. Blue (865-574-4351) and V. K. Sikka (865-574-4351)

PHASE OBJECTIVE: To develop advanced infrared processing in the areas of coating and heat treating.

ULTIMATE OBJECTIVE: To utilize the inherent advantages of radiant heating, which include instant response times, high-power densities, noncontact heating and potential high-energy efficiencies. The primary areas being investigated include coating and heat treating.

TECHNICAL APPROACH: The advantages of radiant heating are applicable in areas where industrial materials currently are experiencing problems resulting from improper heating and lack properties to withstand the given environment, and where the given heating process being utilized is inefficient or not capable of delivering the power density necessary for the overall process.

PROGRESS: A new 300,000-W infrared plasma lamp and processing facility has been brought online that is capable of hardening steel at rates of up to $1 \mathrm{~m} / \mathrm{min}$ with sweep widths as large as $30 \mathrm{~cm}$. This facility allows for fusing of coatings and post fusing of thermal-sprayed coatings with minimal effects on the base material. Results have shown that thermal-sprayed coatings can be fully densified and metallurgically bonded to substrates at scan rates of $0.5 \mathrm{~cm} / \mathrm{s}$. Coatings developed and fused by infrared processing have increased the life of die-casting pins by an order of magnitude.

\section{Other Areas of Industrial Applications of Infrared in FY 1999}

Delphi Automotive Steering Systems (Athens, Alabama) recently installed six single and two double heat-zone infrared boot heaters developed by ORNL. The infrared boot heater is an electric infrared heater and control system designed to heat thermoplastic and polymer boots for applications requiring placement of the boots on steering assemblies, $\mathrm{CV}$ joints, etc. The infrared boot heater heats and expands the boot in a matter of 4 to $5 \mathrm{~s}$. This slight expansion virtually eliminates the force required to install the boot. The subsequent cooling of the boot then makes a better seal than if the boot had been forced on without the application of heat. Responses from assembly line employees who have used this product have been extremely positive. In many cases, ergonomic problems have virtually been eliminated and production has increased. 


\section{PROJECT SUMMARY (continued)}

\section{PROJECT TITLE: Infrared Processing of Materials}

In order to properly forge or die-cast industrial and consumer products, the steel dies utilized in these processes must be preheated to $600^{\circ} \mathrm{F}$ in order to maximize the properties of the expensive dies, typically in the $\$ 10 \mathrm{~K}$ to $\$ 25 \mathrm{~K}$ range and can be an order of magnitude higher. Die heating utilizing gas and conventional electric heating can take up to $4 \mathrm{~h}$, and, in the case of gas, degradation of the die in the process can occur if not properly implemented. A die-insert heater has been fabricated at ORNL and placed in the field for verification of industrial robustness and to quantify die life extension and energy savings. Thermal modeling of heat input and resultant heating rate was accomplished in order to reduce the effects of rapid heat-up in terms of die distortion and preferential tempering. Hardness and dimensional testing to verify the modeling followed the modeling work. Initial results have been outstanding. The dies can be preheated utilizing the infrared insert heater in less than $10 \mathrm{~min}$, compared to $4 \mathrm{~h}$ with gas or electric calrod heaters.

\section{Patents: $1 \quad$ Publications: $1 \quad$ Proceedings: None $\quad$ Presentations: 2}

CRITICAL ISSUES: Industrial robustness of infrared-based systems.

FUTURE PLANS: Continue development of infrared-coating and heat-treating technologies for tooling and other industries. Also, continue demonstrating the industrial robustness of the infrared-based systems in forging and other application industries. Finish quantifying the effects of infrared preheating of tooling on die wear.

POTENTIAL PAYOFF: In the case of die preheating in the forging industry, the immediate payoff is in the fact that the infrared-based preheating takes $20 \mathrm{~min}$. compared with 3 to $4 \mathrm{~h}$ with conventional electric or gas. Also, gas technologies do not always heat the die uniformly, a property which can cause die failure prematurely. If it is shown that the infrared heating reduces die wear, the potential payoff could be very large. A set of forging dies can cost from $\$ 10 \mathrm{~K}$ to $\$ 50 \mathrm{~K}$, depending on size and shape. Other areas of payoff would be in the tooling life extension through coating and the elimination of ergonomic issues with the infrared boot heater. 


\section{SIGNIFICANT ACCOMPLISHMENT}

\section{ADVANCED INDUSTRIAL MATERIALS (AIM) PROGRAM}

\section{Advanced Materials/Processes Infrared Processing of Materials}

ISSUE: Current materials heating systems are often limited due to low power levels. High-density infrared processing can improve materials processing operations and also result in materials with improved properties.

RESULTS: A new 300,000-W infrared lamp and processing facility has been brought online at ORNL that is capable of hardening steel at rates of up to $1 \mathrm{~m} / \mathrm{min}$ with sweep widths as large as $30 \mathrm{~cm}$. This facility allows for fusing of coatings and postfusing of thermal-sprayed coatings with minimal effects on the base material. Results have shown that thermal-sprayed coatings can be fully densified and metallurgically bonded to substrates at scan rates of $0.5 \mathrm{~cm} / \mathrm{s}$.

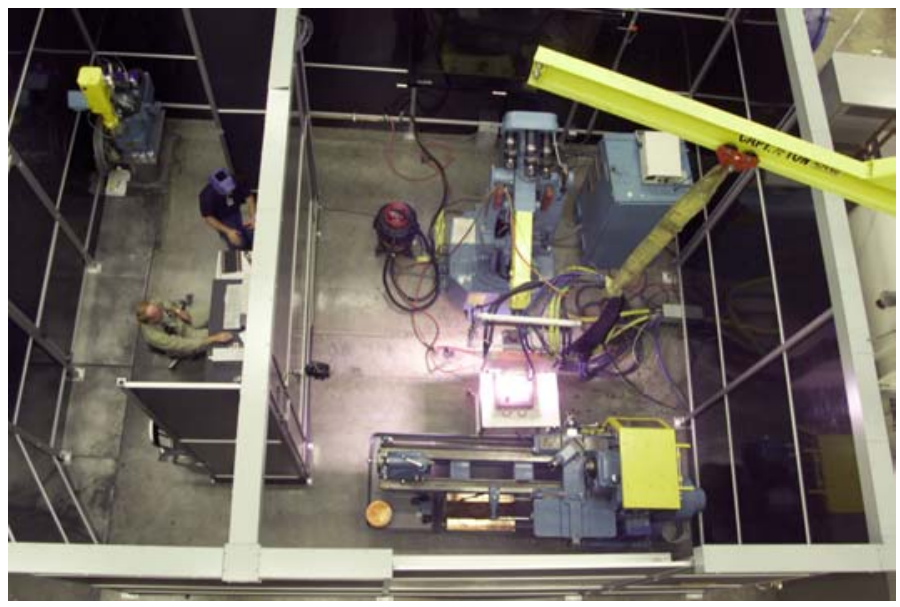

Fig. 1. High-density processing facility utilized for coatings and coated die-casting pins for aluminum die casting.

ENERGY EFFICIENCY: Currently, coatings and heat treatments utilizing the plasma infrared heating system have extended die pin life by an order of magnitude. This die-life extension will minimize the need for change of tooling, which in turn saves energy through the decrease in downtime of die casters and the decreased need for manufacturing new tooling.

Research sponsored by the U.S. Department of Energy, Assistant Secretary for Energy Efficiency and Renewable Energy, Office of Industrial Technologies, Advanced Industrial Materials Program, under contract DE-AC05-00OR22725 with UT-Battelle, LLC. 



\title{
PROJECT SUMMARY
}

\section{ADVANCED INDUSTRIAL MATERIALS (AIM) PROGRAM}

\author{
PROJECT TITLE: Intermetallic Alloy Development and Technology Transfer \\ PHASE: FY 1999 \\ COMPLETION DATE:
}

PERFORMING ORGANIZATION: Oak Ridge National Laboratory (cofunded with the OIT Steel Vision Team)

PRINCIPAL INVESTIGATORS: V. K. Sikka (865-574-5112) and M. L. Santella (865-574-4805)

PHASE OBJECTIVE: To promote the technology transfer of $\mathrm{Ni}_{3} \mathrm{Al}$-based nickel aluminide and FeAl-based iron aluminide alloys in the broadest spectrum of industry possible.

ULTIMATE OBJECTIVE: The ultimate objective is to take advantage of the excellent oxidation and carburization resistances and the higher strength of nickel aluminide and iron aluminide for a broad range of manufacturing-related industry applications. The applications identified to date include materials of construction for chemical processes, heat-treating furnaces in steel industry, fixtures for carburizing furnaces, hot-pressing or forging dies, cast heating elements, and burners for gas-fired furnaces.

TECHNICAL APPROACH: The FeAl-based iron aluminides have beneficial properties, including (1) oxidation resistance, (2) sulfidation resistance, (3) carburization resistance, (4) lower cost, (5) lower density, and (6) molten salt resistance. Since castings are the most likely near-term applications for both nickel and iron aluminides, the technical approach has been to address issues related to castings.

PROGRESS: Worked with all five $\mathrm{Ni}_{3} \mathrm{Al}$ licensees [Alcon Industries, Alloy Engineering \& Casting (AEC) Company, Sandusky International, Stoody Company, and United Defense LP] in addressing production, welding, and application-related issues. Thermal expansion and selected tensile, creep, and fatigue data were developed on the cast eutectic-free alloy IC-438. The specific data generated on IC-438 assisted in the identification and design for the new applications. Several coupons of IC-438 alloy were shipped to potential users. The melting and centrifugal casting trials on FeAl alloy were carried out at AEC. The melting and centrifugal tube casting trials were conducted at Duralloy and Shenango. Tensile and charpy data were generated on samples from Shenango castings. Several coupons of FeAl were supplied to International nickel for developing corrosion data. Several potential users were visited. An HVOF-coated component (air deflector) was installed into service. This deflector gave two times the life of the uncoated part but has been taken out of service.

Patents: 4

Books: 0
Publications: 5

Presentations: 4

\section{Proceedings: 0}

Awards: 1 


\section{PROJECT SUMMARY (continued)}

\section{PROJECT TITLE: Intermetallic Alloy Development and Technology Transfer}

\section{ACCOMPLISHMENTS:}

Licensees: Two potential licensees for iron aluminides worked closely with ORNL for transfer of melting technology and property data on iron aluminides. Both potential licensees had discussions with the Office of Technology Transfer for terms of possible licensee.

\section{Other Successful Technology Transfer Activities as Evidence of Industry Interest:}

1. The 63 pusher furnace assemblies continued operation in carburizing furnaces at Delphi Saginaw. These went into service in March 1997. A detailed microstructural analysis of a fixture removed after a year of service was carried out.

2. A total of 22 rolls of nickel aluminide alloy IC-221M continued operation in the 160-in. furnace at Bethlehem Steel-Burns Harbor Plant in Indiana. A detailed inspection of all rolls was completed and a report prepared.

3. Use of trays in carburizing furnaces at The Timken Company has increased from one to several plants. Use of radiant burner tubes of nickel aluminide has also begun. One set of tubes has completed nearly 9 months of service.

4. A radiant burner tube assembly has been successfully operating at Ford Motor Company for nearly 9 months.

5. Three (17-in.-OD) rolls of nickel aluminide alloy IC-221M were fabricated for installation at U.S. Steel.

CRITICAL ISSUES: Creep data on IC-438, the weldability of IC-438, and identification of hot working conditions for the potentially workable alloy IC-396 LZr are still critical issues for $\mathrm{Ni}_{3} \mathrm{Al}$-based alloys. The commercial welding of IC-221M to HK40 for roll applications needs further optimization. The commercial melting and casting, mechanical properties of commercial heats, and weldability of $\mathrm{FeAl}$ are the critical issues for FeAl-based alloys.

FUTURE PLANS: Continue $\mathrm{Ni}_{3} \mathrm{Al}-$ and FeAl-based alloy technology transfer through solving technical issues, prototype manufacturing, and in-plant testing.

POTENTIAL PAYOFF: Nickel and iron aluminide components for a range of applications can provide benefits of energy savings and U.S. industry gaining the competitive position in the world. Industries benefiting from nickel aluminide technology are steel, chemical, heat treating, forging, and manufacturing. 


\section{SIGNIFICANT ACCOMPLISHMENT}

\section{ADVANCED INDUSTRIAL MATERIALS (AIM) PROGRAM \\ Intermetallic Alloy Development and Commercialization in Support of Industries of the Future}

OBJECTIVE: Enable increased energy efficiency and process efficiencies in the Industries of the Future (IOF) activities through the application of intermetallic alloys.

\section{BENEFITS:}

- $\quad$ Energy savings of up to 53 PJ (50 T Btu) by the year 2010 .

- Improved productivity and product quality.

- Improved environmental benefits.

\section{HIGHLIGHTS:}

- Application of nickel-aluminide rolls was extended to U.S. Steel by fabricating and supplying two $17-$ in.-OD rolls.

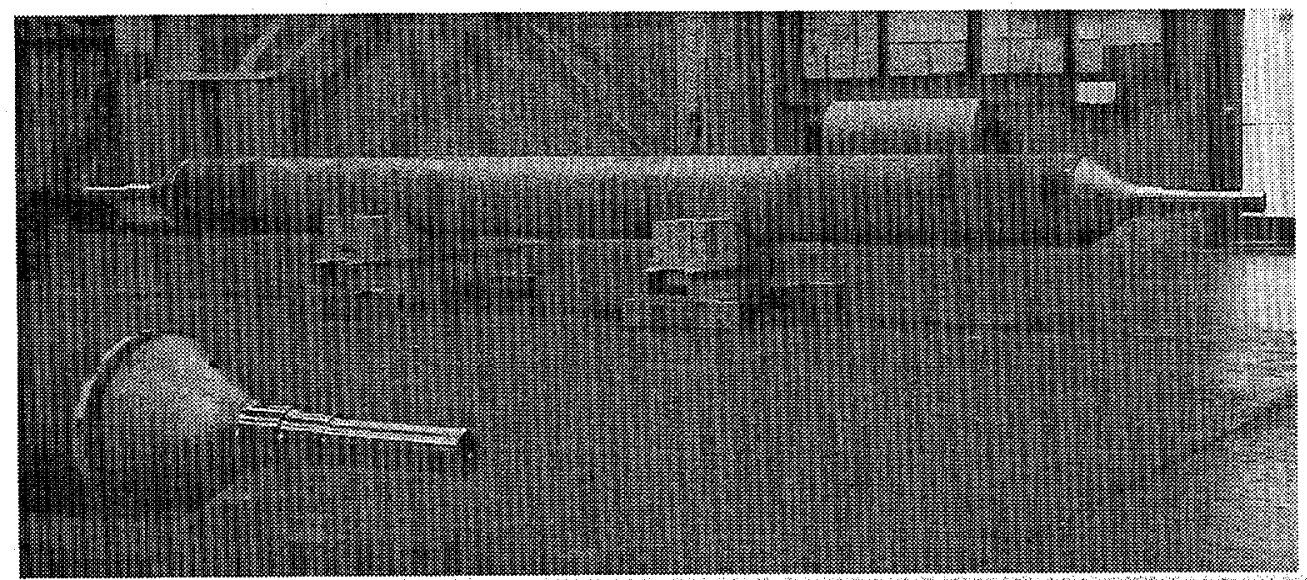

Fig. 1. Two 17-in.-OD rolls of IC-221M fabricated at Sandusky International (Sandusky, Ohio) for installation in austenitization furnace at U.S. Steel (Monroeville, Pennsylvania).

- A major step toward the commercialization of nickel aluminide has been taken through approval of the ASTM Specification for castings.

- The specification designation is A1002-099.

- It represents the first intermetallic to receive its specification approved in ASTM.

- Users can order to ASTM Specification A1002-99 for commercial applications. 



\section{PROJECT SUMMARY}

\section{ADVANCED INDUSTRIAL MATERIALS (AIM) PROGRAM}

\section{PROJECT TITLE: Materials for the Pulp and Paper Industry}

PHASE: FY 1999

\section{COMPLETION DATE:}

PERFORMING ORGANIZATION: Oak Ridge National Laboratory (ORNL); subcontracts, Institute of Paper Science and Technology (IPST) and the Pulp and Paper Research Institute of Canada (PAPRICAN)

PRINCIPAL INVESTIGATOR: James R. Keiser (865-574-4453)

PHASE OBJECTIVES: (1) Identify the environments present when stress-corrosion cracking of 304L stainless steel occurs, (2) determine the effect of thermal cycling on cracking, (3) continue the characterization of cracked tubes, (4) measure residual stresses in unexposed and exposed composite tubes constructed with an outer layer of 304L SS, Alloy 825, Alloy 625, and Alloy 625 weld overlay, (5) predict the stresses in recovery boiler floor tubes during normal operation and during thermal transients, and (6) determine whether the microstructure of an exposed tube has features characteristic of thermal cycling.

ULTIMATE OBJECTIVE: Identify an alternate material or materials and an operational approach that can be used to prevent the cracking seen in 304L/SA210 composite floor tubes.

TECHNICAL APPROACH: Use standard metallographic examination techniques coupled with advanced analytical techniques to characterize unexposed and exposed cracked tubes. Use neutron and X-ray diffraction to measure the residual stresses in composite tubes, and use finite-element modeling to predict stresses under operating conditions. Conduct laboratory studies to identify environments that can cause stresscorrosion cracking and to determine the effects of thermal cycling. Determine the frequency and magnitude of thermal cycles.

PROGRESS: Studies have identified environments that can cause stress-corrosion cracking and have determined operating conditions during which the residual stresses in composite tubes are conducive to stress-corrosion cracking.

$\begin{array}{lll}\text { Patents: None } & \text { Publications: } 8^{*} & \text { Proceedings: None } \\ \text { Books: None } & \text { Presentations: } \sim 15^{* *} & \text { Awards: } 1^{* * *}\end{array}$

\footnotetext{
*Three papers have been published in conference proceedings, and five have been published in the open literature.

**Does not include presentations made at project review meetings.

***Received the American Welding Society's A. F. Davis Silver Medal Award.
} 


\section{PROJECT SUMMARY (continued)}

\section{PROJECT TITLE: Materials for the Pulp and Paper Industry}

\section{ACCOMPLISHMENTS:}

Licenses: None

Known Follow-On Product(s): None

Industry Workshop: Project review meetings are held two times per year.

Technology Transfer or Industrial Interaction: Sixteen paper companies (a decrease because of recent mergers and purchases), four recovery boiler manufacturers, and two tube fabricators are active program participants.

CRITICAL ISSUES: Determination of primary cracking mechanism(s), identification of materials that are resistant to primary mechanism(s) or operating modifications that change conditions that cause cracking are critical issues. In addition, the chemistry of the smelt that is in contact with floor tubes and the characteristics of cracking of primary air port tubes are additional topics that warrant attention.

FUTURE PLANS: Continue work to identify corrodent responsible for stress corrosion cracking; characterize cracked floor and wall tubes provided by paper companies; measure and model the stresses developed in floor and wall composite tubes with some emphasis on bent tubes as well as tubes made from alternate alloys; and work with paper companies to collect smelt samples. Initiate plans for an IEA cooperative project.

POTENTIAL PAYOFF: The energy and financial costs to paper companies resulting from recovery boiler materials problems is enormous due to operational and maintenance costs and the value of lost production. Identification of alternate materials, process changes, and/or modifications of operating conditions will improve operational efficiency.

ESTIMATED ENERGY SAVINGS: Energy benefits occur through decrease in downtime, elimination of energy losses during start-up, and improved normal operations. 


\section{SIGNIFICANT ACCOMPLISHMENT}

\section{ADVANCED INDUSTRIAL MATERIALS (AIM) PROGRAM}

\section{Materials for the Pulp and Paper Industry}

ISSUE: Over the past several years, effort has been directed toward determining the cause and then limiting or eliminating cracking in co-extruded recovery boiler floor tubes. Recent evaluations of other parts of boilers have shown that cracking also occurs in primary air ports. Samples of primary air port tubes have been examined at ORNL, and, as shown in Fig. 1, a few cracks have been observed that went through the stainless steel layer and into the carbon steel. More recently, visits have been made to several mills that have experienced similar cracking to collect more information. As a result of these observations, an activity has been initiated to evaluate primary air port cracking.
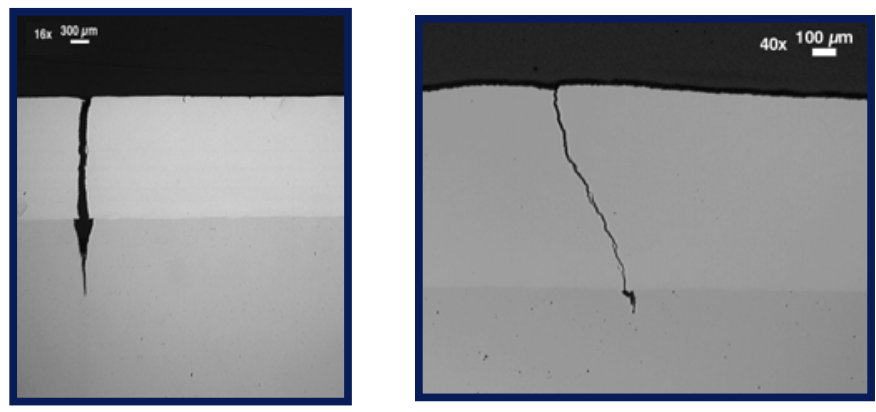

Fig. 1 Examples of cracks seen in two different primary air port opening tubes.

RESULTS: This new activity has five primary tasks: (1) conduct metallographic examination of cracked tubes, (2) determine residual stresses in a cracked primary air port tube, (3) use transmission electron microscopy to search for evidence of thermal cycling, (4) use tube-mounted thermocouples to study thermal behavior of air port tubes, and (5) develop spectroscopic techniques to characterize the fireside chemical environment.

The metallographic examinations are showing that, unlike composite floor tubes, cracks in the air port tubes sometimes continue into the carbon steel. These cracks appear to have characteristics more typical of stress corrosion than thermal fatigue, but further study is needed to address this question.

Temperature measurements using surface-mounted thermocouples are showing some differences between primary air ports that have experienced cracking vs some that have not encountered any cracking. Figure 2 shows some typical temperature measurements for a 12-h period on a "noncracking" air port vs those seen on a "cracking" air port.

Fig. 2. Temperature versus time for thermocouples attached to the surface of primary air port tubes for a port that had not experienced cracking (a) and for a port that had previously had considerable cracking (b).
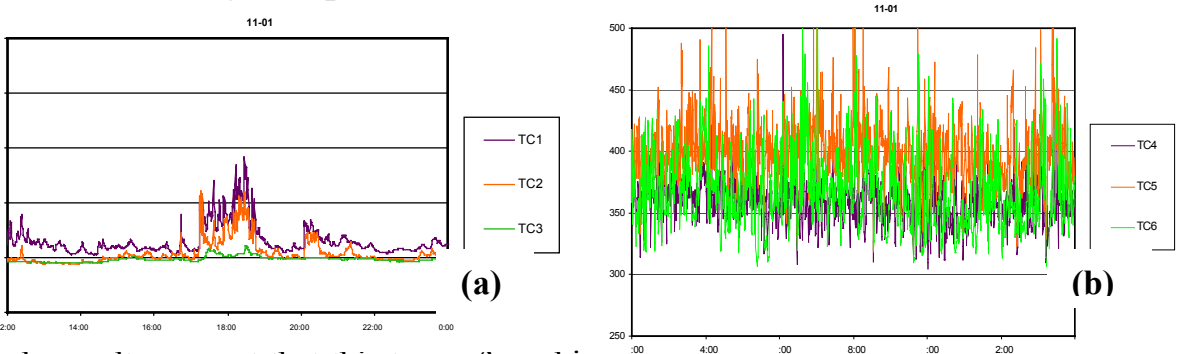

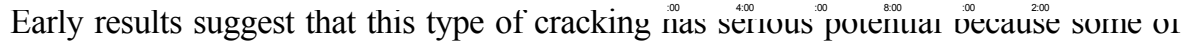
the cracks continue into the carbon steel. Further studies are continuing. 



\section{PROJECT SUMMARY}

\section{ADVANCED INDUSTRIAL MATERIALS (AIM) PROGRAM}

\section{PROJECT TITLE: Synthesis and Design of Silicide Intermetallic Materials \\ PHASE: FY 1999 \\ COMPLETION DATE:}

PERFORMING ORGANIZATION: Los Alamos National Laboratory (LANL) (project funded by the Glass Vision Team)

PRINCIPAL INVESTIGATORS: J. J. Petrovic (505-667-0125) and R. G. Castro (505667-5191)

PHASE OBJECTIVES: Interact with Accutru International Corporation, Combustion Tec. Inc., and Exotherm Corporation to develop $\mathrm{MoSi}_{2}$-based protection sheaths for glass-processing sensors. Develop advanced plasma spray-forming techniques and facilities for the fabrication of $\mathrm{MoSi}_{2}-\mathrm{Al}_{2} \mathrm{O}_{3}$ laminate and functionally graded composite tubes. Develop joining techniques of $\mathrm{MoSi}_{2}$ materials to stainless steel.

ULTIMATE OBJECTIVE: To develop $\mathrm{MoSi}_{2}$-based high-temperature structural silicide materials with optimum combinations of properties for applications of importance to U.S. processing industries and, particularly, the glass-processing industry.

TECHNICAL APPROACH: Use advanced plasma spray-forming approaches to fabricate $\mathrm{MoSi}_{2}-\mathrm{Al}_{2} \mathrm{O}_{3}$ laminate composite tubes with significantly improved thermal shock resistance, for glass sensor-protection sheaths. Determine and characterize the materials parameters that maximize thermal shock resistance, oxidation resistance, and glass corrosion resistance of $\mathrm{MoSi}_{2}$-based composite tubes.

PROGRESS: Advanced plasma spray-forming techniques and facilities were developed for the fabrication of $\mathrm{MoSi}_{2}$-ceramic laminate and functionally graded composite tube geometries. A baseline test of a plasma spray-formed polycrystalline $\mathrm{MoSi}_{2}$ periscope sight tube for a Combustion Tec glass-furnace video monitoring system was conducted at the Owens Illinois Container Glass Plant in Lexington, North Carolina.
Patents: None
Publications: 7
Proceedings: 1
Books: None
Presentations: 5
Awards: None

ACCOMPLISHMENTS: $50 \mathrm{Vol} \% \mathrm{MoSi}_{2}-50 \mathrm{Vol} \% \mathrm{Al}_{2} \mathrm{O}_{3}$ laminate composite tubes have been successfully fabricated by plasma spray-forming. $\mathrm{MoSi}_{2}-\mathrm{Al}_{2} \mathrm{O}_{3}$ composites were made with layer thicknesses of $0.95 \mathrm{~mm}, 0.34 \mathrm{~mm}$, and $0.08 \mathrm{~mm}$. $\mathrm{MoSi}_{2}$-coated $\mathrm{Al}_{2} \mathrm{O}_{3}$ thermocouple sheaths were fabricated and their oxidation and thermal shock behavior characterized. Joining techniques for $\mathrm{MoSi}_{2}$ to stainless steel have been developed based on cobalt metallic glasses.

Licenses: None

Industry Workshop: None

Known Follow-On Product(s): $\mathrm{MoSi}_{2}$ gas injection tube for glass melting (Kanthal) 


\section{PROJECT SUMMARY (continued)}

\section{PROJECT TITLE: Synthesis and Design of Silicide Intermetallic Materials}

Technology Transfer or Industrial Interaction: Accutru International, Combustion Tec, and Exotherm: Plasma Process

CRITICAL ISSUES: Development of high thermal shock resistant and high oxidation/corrosion resistant $\mathrm{MoSi}_{2}$-based composite tubes for sensor protection sheath applications.

FUTURE PLANS: We will characterize the material parameters that maximize the thermal shock resistance of $\mathrm{MoSi}_{2}-\mathrm{Al}_{2} \mathrm{O}_{3}$ laminate composites produced by plasma sprayforming. We will characterize the properties of Exotherm combustion synthesized silicide composite tubes. We will fabricate an Accutru temperature sensor silicide protective sheath for testing in a Corning glass furnace. We will fabricate $\mathrm{MoSi}_{2}-\mathrm{Al}_{2} \mathrm{O}_{3}$ laminate composite video sensor system periscope sight tubes for glass furnace testing by Combustion Tec. We will investigate the $\mathrm{MoSi}_{2}$-zircon and $\mathrm{MoSi}_{2}$-mullite composite systems.

POTENTIAL PAYOFF: The potential payoff for industrial applications of hightemperature $\mathrm{MoSi}_{2}$-based structural silicides is very high. Major industrial applications exist in the areas of high-temperature oxidation/corrosion-resistant sensor protection sheaths, glass- and metal-processing equipment, industrial gas burners and lances, furnace heating elements and radiant gas heaters, and high-temperature industrial erosion/wear components. An environmental benefit also exists since $\mathrm{MoSi}_{2}$-based radiant burners and heaters that can burn mixtures of pure oxygen and natural gas will reduce $\mathrm{NO}_{\mathrm{x}}$ and $\mathrm{CO}_{2}$ emissions.

ESTIMATED ENERGY SAVINGS: Potential energy savings of 0.2 Quads can occur from the use of $\mathrm{MoSi}_{2}$-based materials in industrial applications. 


\section{SIGNIFICANT ACCOMPLISHMENT}

\section{ADVANCED INDUSTRIAL MATERIALS (AIM) PROGRAM}

\section{Thermal Shock Resistant $\mathrm{MoSi}_{2}-\mathrm{Al}_{2} \mathrm{O}_{3}$ Plasma Spray-Formed Composite Tubes for Sensor Protection Sheaths}

ISSUE: Advanced sensors for glass processing and glass furnaces require protective sheath materials that are both thermal shock resistant and oxidation/corrosion resistant.

RESULTS: $\mathrm{MoSi}_{2}-\mathrm{Al}_{2} \mathrm{O}_{3}$ laminate and functionally graded composite tubes have been fabricated using advanced plasma spray-forming techniques and facilities. We have made $50 \mathrm{Vol} \% \mathrm{MoSi}_{2}-50 \mathrm{Vol} \% \mathrm{Al}_{2} \mathrm{O}_{3}$ laminate composites with layer thicknesses of $0.95 \mathrm{~mm}, 0.34 \mathrm{~mm}$, and $0.08 \mathrm{~mm}$. The material parameters that maximize thermal shock resistance are being evaluated. These $\mathrm{MoSi}_{2}-\mathrm{Al}_{2} \mathrm{O}_{3}$ composite tubes will be employed for glass furnace temperature and video monitoring sensor-protection sheaths.

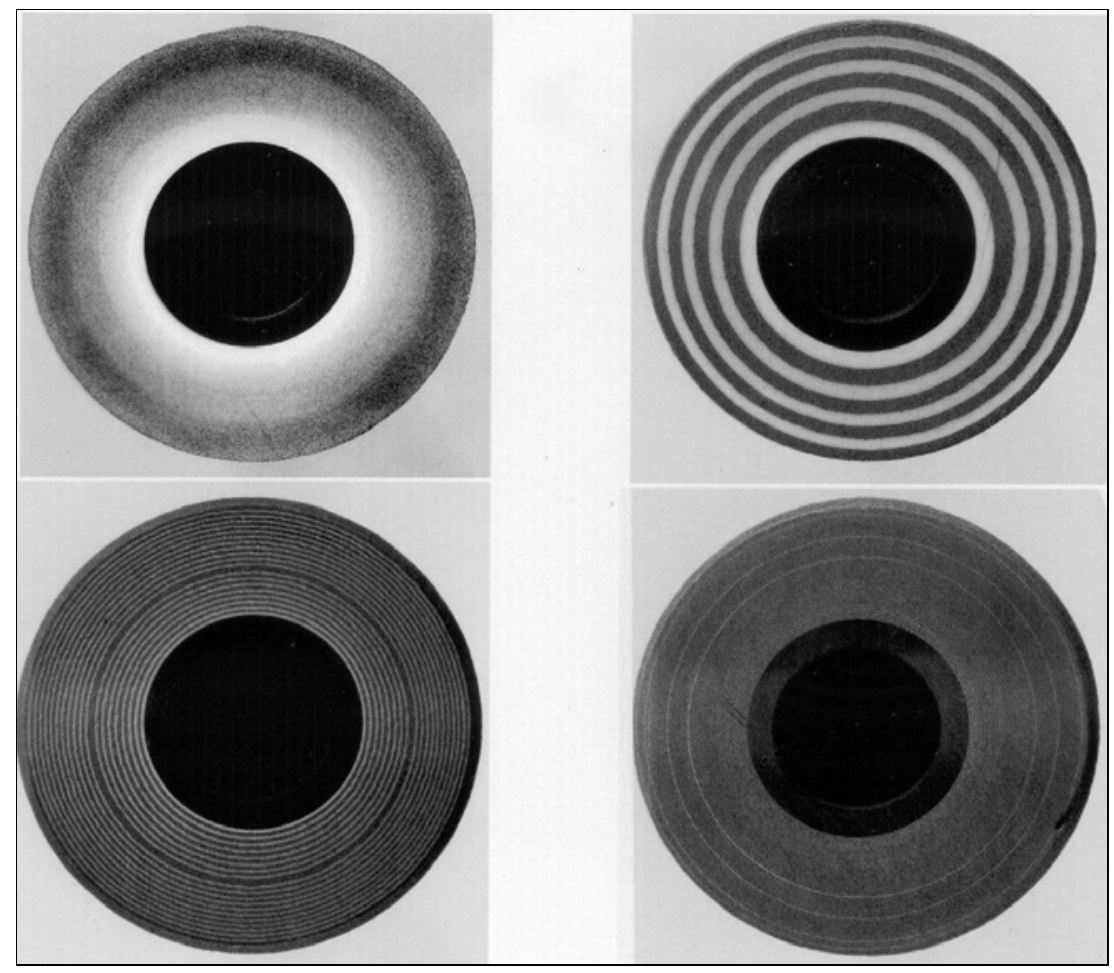

ENERGY EFFICIENCY: Potential energy savings of 0.2 Quads may occur from the use of $\mathrm{MoSi}_{2}$-based materials in industrial applications such as glass processing.

Research sponsored by the U.S. Department of Energy, Assistant Secretary of Energy Efficiency and Renewable Energy, Office of Industrial Technologies, Glass Vision Team, under contract to the Los Alamos National Laboratory. 



\title{
PROJECT SUMMARY
}

\section{ADVANCED INDUSTRIAL MATERIALS (AIM) PROGRAM}

\author{
PROJECT TITLE: Uniform-Droplet Spray Forming \\ PHASE: FY 1999 \\ COMPLETION DATE:
}

PERFORMING ORGANIZATIONS: Oak Ridge National Laboratory (ORNL), Massachusetts Institute of Technology (MIT), and Northeastern University

PRINCIPAL INVESTIGATORS: V. K. Sikka (865-574-4351), C. A. Blue (865-574-4351), J. H. Chun, (617-253-1759), and T. Ando, (617-628-5000, ext. 5163)

PHASE OBJECTIVE: To translate the uniform-droplet spray (UDS) process to hightemperature materials and promote technology transfer of the process to the broadest spectrum of industry as possible.

ULTIMATE OBJECTIVE: To take advantage of the extremely uniform droplet and size distribution produced by the process for a broad range of manufacturing-related industrial applications. The applications identified to date include ball-grid array- (BGA) type integrated-circuit (IC) packaging, water filtration systems (bronze), shot production, spray forming, ball bearing production, aluminum sheet production, and powder production.

TECHNICAL APPROACH: Since many applications exist for uniform droplets of high-temperature materials, the technical approach has been to address issues relating to the development of a high-temperature uniform system. These include (1) development of low- and medium-temperature systems to identify a potential high-temperature assembly, (2) determine the low- and medium-temperature optimum-spraying conditions for materials with melting points between 230 and $1250^{\circ} \mathrm{C}$, (3) verify size distribution and repeatability of droplets, (4) identify and resolve any problems encountered with the low- and medium-temperature systems, (5) identify spray parameters for multiorifice spraying, (6) study impact and solidification of droplets, and (7) translate acquired knowledge to commercial sector.

\section{PROGRESS:}

High-Temperature System. The high-temperature apparatus has been assembled, and preliminary testing has been completed. This system has allowed for the fabrication of uniform droplet of materials with melting points in excess of $1250^{\circ} \mathrm{C}$. These materials include aluminum, bronze, and copper. This system has aided in the development of the UDS system for industrial practices, commercial unit present at Uniform Metal Technologies. Three companies have spent substantial time at ORNL gathering the technical knowledge for translation of the process to industry. Two important areas of advanced materials processing are being addressed, namely advanced particulate production and controlled spray deposition. While the former area deals with the production and controlled solidification of UDSs, the latter area deals with controlled 


\section{PROJECT SUMMARY (continued)}

\section{PROJECT TITLE: Uniform-Droplet Spray Forming}

deposition of UDSs. Products in the particulate area are spherical balls and flakes of metals and alloys produced by the solidification of a UDS. Strong interest has already been identified in electronics packaging in which UDS-processed BGA solder balls are expected to replace those produced by conventional, cut-wire spheroidization. The advantage of the UDS process is expected to drive the technology toward higher melting temperature BGA balls with smaller diameters required in higher-density packaging. Products in the spray-deposition area vary from coatings to near-net-shape or net-shape spray deposits and is characterized by ultimate levels of microstructural control permitted by the decoupled spray parameters. A substantial amount of work has been accomplished with multiorifice spraying, field interactions, droplet impact and solidification. Among the new opportunities envisioned are porosity-free deposition, precise microstructural control, production of novel microstructures and materials, and the potential for net-shape and near net-shape processing. The joint study has generated significant fundamental knowledge on the droplet generation, droplet manipulation, in-flight solidification, and droplet deposition, with the particular objective of applying the UDS process to the continuous production of flat products (e.g., sheet, strip, and coatings). Current efforts are focused on aluminum sheet production and commercial transfer of the technology. Also, a technology has been developed for the production of large-diameter spheres of stainless steel and is applicable to most materials without equipment change.

\section{Patents: $1 \quad$ Publications: $17 \quad$ Proceedings: None Presentations: 11}

CRITICAL ISSUES: Orifice clogging and materials compatibility at high temperatures

FUTURE PLANS: Continue acquiring knowledge through solving technical issues during industrial implementation of a high-temperature uniform droplet. Continue to apply the UDS technology to near-net-shape fabrication of sheet. Also, continue developing interest in the industrial sector and transfer technology of the low-, medium-, and high-temperature systems.

POTENTIAL PAYOFF: The UDS process allows for the fabrication of mono-sized powders near $100 \%$ yield, thereby eliminating the sieving of powder as performed with the present powder-forming technologies. Also, the powders are spherical and possess a more uniform microstructure, which results in a superior powder. The elimination of sieving translates into a reduction of the overall production cost through saving energy. Also, work is in progress to raster the jet electromagnetically or a substrate mechanically in order to accomplish near-net-shape fabrication of parts. This will result in parts with a controlled microstructure and allow for the elimination of tooling. It also can allow for the formation of parts from materials that are inherently difficult to machine and/or cast. The points demonstrate massive energy savings and the utilization of new materials. 


\title{
SIGNIFICANT ACCOMPLISHMENT
}

\section{ADVANCED INDUSTRIAL MATERIALS (AIM) PROGRAM}

\author{
High-Temperature Uniform-Droplet Technology Licensed \\ and a Company Developing a Prototype Unit
}

ISSUE: A uniform-droplet spray (UDS) process has been for spraying low-melting-point materials. The most potential for the UDS process is in the medium- to high-meltingtemperature alloys.

RESULTS: The low-, medium-, and high-temperature UDS systems have been fabricated at Oak Ridge National Laboratory. Results have been accomplished in the spray-deposition area. Materials in the spray-deposition area vary from coatings to nearnet-shape or net-shape spray deposits and are characterized by ultimate levels of microstructural control permitted by the decoupled spray parameters. Among the new opportunities envisioned are porosity-free deposition, precise microstructural control, production of novel microstructures and materials, and the potential for net-shape and near-net-shape processing. The joint study also has generated significant knowledge on droplet generation, droplet manipulation, in-flight solidification, droplet impact, and deposition, with the particular objective of applying the UDS process to the continuous production of flat products (e.g., sheet, strip, and coatings). Current efforts are focused on aluminum sheet production and transfer of technology to industry.

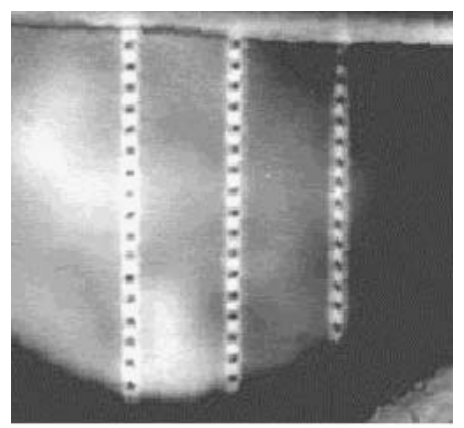

Fig. 1. Multi-orifice spraying of aluminum for sheet fabrication.

ENERGY EFFICIENCY: The UDS process, which allows for the fabrication of monosized powders near $100 \%$ yield, eliminates the sieving of powder as performed with the present powder-forming technologies. Also, the powders are spherical and possess a more uniform microstructure, which results in a superior powder. The elimination of sieving translates into a reduction of the overall production cost through saving energy. Also, work is in progress to raster the jet electromagnetically or the substrate mechanically to accomplish near net-shape fabrication of parts. This will result in parts with a controlled microstructure and allow for the elimination of tooling. It also can allow for the formation of parts from materials that are inherently difficult to machine and/or cast. The points demonstrate energy savings and the utilization of new materials.

Research sponsored by the U.S. Department of Energy, Assistant Secretary for Energy Efficiency and Renewable Energy, Office of Industrial Technologies, Advanced Industrial Materials Program, under contract DE-AC05-00OR22725 with UT-Battelle, LLC. 

NEW MATERIALS AND PROCESSES 



\section{PROJECT SUMMARY}

\section{ADVANCED INDUSTRIAL MATERIALS (AIM) PROGRAM}

PROJECT TITLE: Advanced Industrial Materials (AIM) Fellowship Program

PHASE: FY 1999

\section{COMPLETION DATE:}

PERFORMING ORGANIZATIONS: Oak Ridge Institute for Science and Education, Oak Ridge, Tennessee; Ames Laboratory, Ames, Iowa; University of Alabama, Tuscaloosa, Alabama; Iowa State University, Ames, Iowa; Oak Ridge National Laboratory (ORNL), Oak Ridge, Tennessee.

PRINCIPAL INVESTIGATORS: K. Ketner, Oak Ridge Institute for Science and Education; D. K. Hoffman, R. B. Thompson, and I. E. Anderson, Ames Laboratory; S. McElroy and R. Reddy, University of Alabama; T. E. Bloomer, Iowa State University; P. J. Maziasz and V. K. Sikka, Oak Ridge National Laboratory.

PHASE OBJECTIVE: The Graduate Fellowship Program focused toward helping students who are currently underrepresented in the nation's pool of scientists and engineers, enter and complete advanced degree programs.

ULTIMATE OBJECTIVE: The objectives of the program are to: (1) establish and maintain cooperative linkages between DOE and professors at universities with graduate programs leading toward degrees or with degree options in Materials Science, Materials Engineering, Metallurgical Engineering, and Ceramic Engineering — the disciplines most closely related to the AIM Program at ORNL; (2) strengthen the capabilities and increase the level of participation of currently underrepresented groups in master's degree programs; and (3) offer graduate students an opportunity for practical research experience related to their thesis topic a research assignment or practicum at ORNL and Ames Laboratory. The program is administered by the Oak Ridge Institute for Science and Education (ORISE).

TECHNICAL APPROACH: Offer fellowships for master's degree program in materials science-related academic fields.

PROGRESS: Two fellowship recipients were involved in the project. (See following Significant Accomplishments: "AIM Fellowship Program: Surface Modification of Aluminides Processed by a Nd-YAG Laser and a Plasma Arc Lamp," Sherman McElroy, University of Alabama; "AIM Fellowship Program: Microstructural and Mechanical Properties of Tin-Silver-Copper + Transition Metal Solder.” 



\section{SIGNIFICANT ACCOMPLISHMENT}

\section{ADVANCED INDUSTRIAL MATERIALS (AIM) PROGRAM}

\section{AIM Fellowship Program: Surface Modification of Aluminides Processed by a Nd-YAG Laser and a Plasma Arc Lamp}

ISSUE: A series of experiments have been conducted on $\mathrm{TiAl}, \mathrm{Ti}_{3} \mathrm{Al}, \mathrm{FeAl}, \mathrm{Fe}_{3} \mathrm{Al}$, and $\mathrm{Ni}_{3} \mathrm{Al}$ using a Nd-YAG laser and the Vortex (plasma arc lamp) to explore the possibility of applying laser- and arc-lamp processing on aluminides and to help in the understanding of laser and Vortex processing of aluminides in the future.

RESULTS: Using a Nd-YAG laser, laser processing of a series of Ti-Al alloys including pure $\mathrm{Ti}, \mathrm{Ti}_{3} \mathrm{Al}, \mathrm{TiAl}, \mathrm{TiAl}_{3}$, and $2024 \mathrm{Al}$ alloy have been studied (see Fig. 1). SEM, XPS, and optical microscopy were used to determine the surface morphological, chemical, and compositional characteristics of the laser-processed samples. Analysis of results showed that cracks along grain boundaries caused by rapid heating and cooling of laser processing were the dominant characteristics of the surface morphologies of the laserprocessed samples. Al content in the Ti-Al alloys played a very important role in crack initiation and/or development. The more Al content in the samples, the more severe the cracks that developed after laser processing under the same conditions.

A high-power infrared arc lamp was used to surface-treat TiAl, $\mathrm{Ti}_{3} \mathrm{Al}, \mathrm{FeAl}, \mathrm{Fe}_{3} \mathrm{Al}$, and $\mathrm{Ni}_{3} \mathrm{Al}$. SEM, XPS, and optical microscopy were used to determine the surface morphological, chemical, and compositional characteristics of the Vortex-processed samples. Analysis of results showed that annealing increases the ductility of the aluminides by making them more uniform, a property that is evident by the decrease in their Rockwell hardness values. A surface-temperature estimation equation is in development for the Vortex-processing experiments. Modeling was also performed with the Deform 2 program.

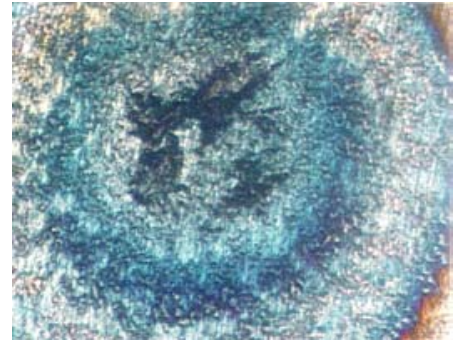

(a)

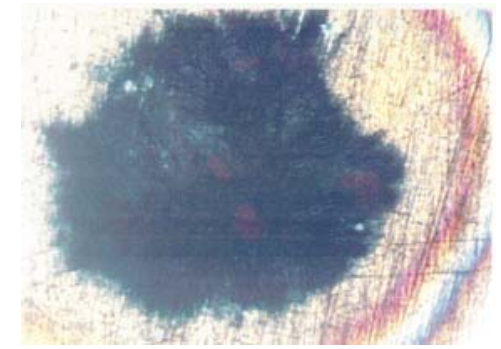

(b)

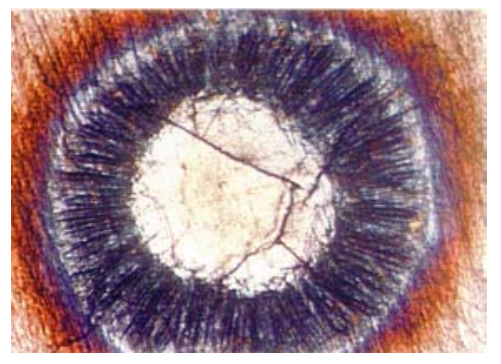

(c)

Fig. 1. Optical micrographs of laser-processed spots on (a) pure $\mathrm{Ti}$, (b) $\mathrm{Ti}_{3} \mathrm{Al}$, and (c) TiAl, as well as $\mathrm{TiAl}_{3}$, and $2024 \mathrm{Al}$ alloy; E, $2 \mathrm{~kW}$;, $10 \mathrm{~ms}$; R, $5.7 \mathrm{~Hz}$; 1 pulse.

Research performed at the University of Alabama and Oak Ridge National Laboratory and sponsored by the U.S. Department of Energy, Assistant Secretary for Energy Efficiency and Renewable Energy, Office of Industrial Technologies, Advanced Industrial Program; the National Science Foundation; and the Department of Metallurgical and Materials Engineering at the University of Alabama. 



\section{SIGNIFICANT ACCOMPLISHMENT}

\section{ADVANCED INDUSTRIAL MATERIALS (AIM) PROGRAM}

\section{AIM Fellowship Program: Microstructural and Mechanical Properties of Tin-Silver-Copper + Transition Metal Solder}

\section{ISSUE: Development of Lead-Free Solders}

RESULTS: This study attempted to perform a preliminary Pb-free solder alloy selection from a series of experimental and baseline alloys that had been identified in previous work for possible application in harsh environments under severe thermal mechanical fatigue (TMF) conditions. Asymmetric four-point-bend tests that utilized soldered butt joints $(\mathrm{Cu} / \mathrm{solder} / \mathrm{Cu})$ were used to rank a series of solder alloys in terms of solder joint shear strength at two test temperatures. The mechanical test results, shown in Fig. 1, indicated that the Sn-3.5Ag baseline alloy and all of the Sn-Ag-Cu and Sn-Ag-Cu-X experimental alloys fell within similar shear strength ranges at both test temperatures, ambient $\left(22^{\circ} \mathrm{C}\right)$ and $170^{\circ} \mathrm{C}$. However, Sn-3.5Ag solder showed evidence of susceptibility to shear strength degradation with a minor variation of soldering-process parameters. This susceptibility may be cause to diminish the ranking of Sn-3.5Ag or may impose increased process-control restrictions on manufacturers. The consistently low shearstrength values of the $\mathrm{Sn}-0.7 \mathrm{Cu}$ solder joints do not suggest much promise for this alloy as a high-performance $\mathrm{Pb}$-free solder, but it still should remain a useful $\mathrm{Pb}$-free solder for lower-stress applications (i.e., through-hole joints). The Sn-3.6Ag-1Cu alloy appears to be preferred of the alloys included in this study because of consistent high-level shear strengths and low alloy-component costs.

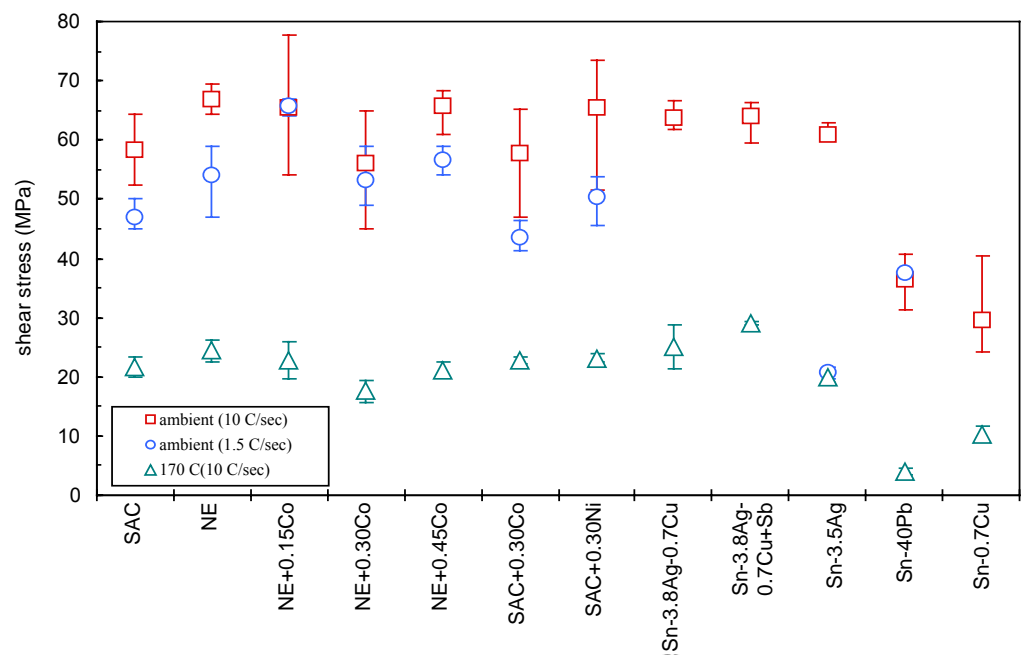

Fig. 1. Summary of ambient temperature $\left(22^{\circ} \mathrm{C}\right)$ and $170^{\circ} \mathrm{C}$ shear-strength results prepared at two different cooling rates for various lead-free solders, as well as for $\mathrm{Sn}-40 \mathrm{~Pb}$. A cross-head speed of $0.1 \mathrm{~mm} / \mathrm{min}$. was used for all specimens.

Research performed at Iowa State University and Ames Laboratory and sponsored by the U.S. Department of Energy, Assistant Secretary for Energy Efficiency and Renewable Energy, Office of Industrial Technologies, Advanced Industrial Materials Program. 



\section{PROJECT SUMMARY}

\section{ADVANCED INDUSTRIAL MATERIALS (AIM) PROGRAM}

\section{PROJECT TITLE: Advanced Materials for High-Temperature, Liquid-Metal Corrosion and Erosion Resistance}

PHASE: FY 1999

COMPLETION DATE:

PERFORMING ORGANIZATION: Los Alamos National Laboratory (LANL)

PRINCIPLE INVESTIGATORS: Mitchell Trkula (505-667-0591) and Michael Nastasi (505-667-7007)

PHASE OBJECTIVE: To develop novel plasma-based surface engineering and organometallic coating technologies for the production of corrosion- and erosionresistant, thermodynamically stable, and highly adherent conformal coatings on die materials used to cast aluminum and other metals.

ULTIMATE OBJECTIVE: To produce a cost-effective and industrially relevant surface engineering process through the combination of materials science, plasma immersion processing, and organometallic chemical vapor deposition techniques. This process should be non-line-of-sight to allow easy processing of complex shapes and also should be inherently scaleable to allow for the processing of extremely large components. The immediate objective is to develop corrosion- and erosion-resistant, thermodynamically stable, and highly adherent conformal coatings on die materials used to cast aluminum and other metals. Follow-on objectives may include development of wear, erosion, and reduced-friction coatings.

TECHNICAL APPROACH: Candidate corrosion- and erosion-resistant coatings will be chosen based on an analysis of thermodynamic and thermal expansion for the total system of liquid metal/coating/substrate. Coating synthesis will employ a combination approach using organometallic chemical vapor deposition (OMCVD) with plasma immersion ion processing (PIIP). The PIIP process will be used to physically and chemically clean the substrate surface, ion-implant the coating species into the substrate surface to provide a graded transition to the coating, and will, in conjunction with OMCVD, deposit thick, adherent, and conformal surface coatings.

PROGRESS: Discussions between Los Alamos and a variety of industries have been ongoing over the last year. These industries include Chrysler, Empire Hard Chrome, Alcoa, Ford Motor Company, Reynolds, Boeing Corporation, and Schlumberger. A Commerce Business Daily ad was published on this project, and we are reviewing the responses. A CRADA between LANL and Pratt and Whitney is in progress.

Patents: None

Books: None
Publications: 2

Presentations: 3
Proceedings: None

Awards: None 


\section{PROJECT SUMMARY (continued) \\ PROJECT TITLE: Advanced Materials for High-Temperature, Liquid-Metal Corrosion and Erosion Resistance}

ACCOMPLISHMENTS: Coatings of TiN and Cr-O-C have been produced on a variety of substrate materials. Wetting experiments show that $\mathrm{Cr}-\mathrm{C}-\mathrm{O}$ coatings provide effective protection against reactions between molten aluminum and steel substrates. The TiN coatings were smooth and stoichiometric, and they passed our initial wetting experiments.

\section{Licenses: None Known Follow-On-Product(s): None}

Industry Workshops: None Technology Transfer or Industrial Interactions: None

CRITICAL ISSUES: Integration of Cr-O-C coatings with OMCVD process and integration of TiN with PIIP process.

FUTURE PLANS: To investigate further the synthesis of $\mathrm{Cr}-\mathrm{O}-\mathrm{C}$ and TiN coatings and evaluate their properties. We plan to determine the role of deposition parameters on the coating composition, deposition rate, ultimate coating thickness, surface mechanical properties (i.e., hardness, wear resistance, friction), coating adhesion and delamination, and aluminum wetting properties.

POTENTIAL PAYOFF: The potential payoff for industrial application in the area of Al die-casting is anticipated to be very high. The development of a low-cost surfaceengineering process for the production of nonwetting and erosion-resistant surface coatings is highly desirable. Cost savings can be realized from the extension of die life, reduced energy losses due to thermal cycling, and the improved surface finish of the cast product.

ESTIMATED ENERGY SAVINGS: We have studied material lifetime and its effect on aluminum die casting in the automotive industry. Estimates indicate that dye life extension for this industry alone can result in energy savings of $3.3 \times 10^{12}$ to $3.3 \times 10^{13}$ Btu/year. 


\section{SIGNIFICANT ACCOMPLISHMENT}

\section{ADVANCED INDUSTRIAL MATERIALS (AIM) PROGRAM}

\section{Advanced Materials for High-Temperature, Liquid-Metal Corrosion and Erosion Resistance}

ISSUE: Die life is a major consideration in the die-casting process. Die degradation occurs principally by thermal fatigue (i.e., heat checking), erosive and abrasive wear, chemical attack and/or corrosion, and soldering between the die and casting material. Our approach to solving this problem is to develop novel plasma-based surface-engineering technologies for the production of corrosion- and erosion-resistant, thermodynamically stable, and highly adherent conformal coatings on die materials used to cast aluminum and other metals.

RESULTS: Synthesis of a Cr-O-C coating was accomplished through the combined approach of using organometallic chemical vapor deposition (OMCVD) with plasma immersion ion processing (PIIP). The organometallic chemical source for this coating was $\mathrm{Cr}(\mathrm{CO})_{6}$. The PIIP process was used to sputter-clean the substrate surface prior to coating deposition to provide plasma generation of the $\mathrm{Cr}(\mathrm{CO})_{6}$ gas and to supply a substrate bias voltage during coating deposition. The data show the results of wetting experiments between molten aluminum and steel substrates, both with and without the PIIP-generated Cr-O-C coating. The data also show that a $\mathrm{Cr}-\mathrm{O}-\mathrm{C}$ coating provides effective protection against reactions between molten aluminum and 304 stainless steel and H13 steel substrates. In parallel to $\mathrm{Cr}-\mathrm{O}-\mathrm{C}$ work, we have deposited TiN by MOCVD. The TiN films are smooth and stoichiometric, and they contain only a few atomic percent hydrogen. These films pass the molten aluminum test. Currently, we are adapting Cr-O-C to OMCVD and TiN to PIIP.

ESTIMATED ENERGY SAVINGS: We have studied material lifetime and its effect on aluminum die casting in the automotive industry. Estimates indicate that die life extension for this industry alone can result in energy savings of $3.3 \times 10^{12}$ to $3.3 \times 10^{13}$ Btu/year.

Research performed at Los Alamos National Laboratory, sponsored by the U.S. Department of Energy under programs from the Office of Energy Efficiency and Renewable Energy/Office of Industrial Technologies and the Office of Basic Energy Science/Division of Materials Science. 



\section{PROJECT SUMMARY}

\section{ADVANCED INDUSTRIAL MATERIALS (AIM) PROGRAM}

\section{PROJECT TITLE: Development of Improved Refractories}

PHASE: FY 1999

COMPLETION DATE: FY 2001

PERFORMING ORGANIZATIONS: Oak Ridge National Laboratory (ORNL) and the University of Missouri at Rolla (UMR) (project cofunded with Glass Vision Team)

PRINCIPAL INVESTIGATORS: Andrew A. Wereszczak/ORNL (865-574-7601), Kenneth C. Liu/ORNL (865-574-5116), Bruce A. Pint/ORNL (865-576-2897), Musa Karakus/UMR (573-341-6561), and Robert E. Moore/UMR (573-341-4401)

PHASE OBJECTIVE: Conduct compressive creep, corrosion, and dimensional stability studies on fused-grain mullites and fusion-cast aluminas. Perform pre- and post-testing analyses to correlate microstructural changes with the determined creep, corrosion, and dimensional stability performances. Perform postmortem analyses on conventional silica refractories from glass-production furnaces and correlate microstructural changes to changes in thermal conductivity.

ULTIMATE OBJECTIVE: Generate an engineering database on the thermomechanical and thermophysical properties of several different commercial refractory categories that are candidate materials for glass-melting furnace superstructures including those in oxyfuel fired furnaces.

TECHNICAL APPROACH: Thermomechanical and thermophysical data will be generated on competing brands of commercially available refractories that are candidate materials for glass-furnace superstructures. The data will be made available to glass manufacturers so that they may (1) make equitable comparisons of competing brands to facilitate their choice of refractory brand for their applications and (2) provide design data to their furnace-design-engineers for which they may use to optimize superstructure design.

PROGRESS: Four different areas were investigated in FY 1999 that addressed the above issues. Completion of the test matrix of conventional silica refractories was completed in early FY 1999 and a ORNL/TM report was written, published, and distributed in March 1999. Second, two conventional silica bricks from float-glass and TV-panel furnaces were analyzed for changes to its structure from their respective 10 and 6 years of service. Microstructural and phase changes were found and were a function of position away from the bricks' hot-face end. As a consequence of these changes, the bricks' thermal conductivity increased with the exception of those locations where substantial porosity was found. A thermal analysis model was examined using finite-element analysis and found that the temperature of the silica brick likely had increased with service time due to the increased thermal conductivity that had resulted from the microstructural changes. Third, the thermomechanical and thermophysical characterization of ten fused-grain 


\section{PROJECT SUMMARY (continued)}

\section{PROJECT TITLE: Development of Improved Refractories}

mullite refractories (candidate refractory for borosilicate glass production) was initiated. Thermal conductivity and corrosion analyses were completed. Completion of their creep testings is expected in early FY 2000. Finally, the thermomechanical and thermophysical characterizations of two fusion-cast alumina refractories (best candidates for oxy-fuel fired furnaces) were initiated. Thermal conductivity measurements have been completed. Their creep performances are being examined as a function of block position (i.e., microstructure) as well as temperature and stress, so the completion of the creep test matrix requires more test time than that for the mullite refractories. Several articles and reports were written describing the project's results.

$\begin{array}{lll}\text { Patents: None } & \text { Publications: } 6 & \text { Proceedings: } 1 \\ \text { Books: None } & \text { Presentations: } 5 & \text { Awards: None }\end{array}$

ACCOMPLISHMENTS: See Progress section above.

\section{Licenses: None Known Follow-On Product(s): None Industry Workshop: None}

Technology Transfer or Industrial Interaction: Two GIAC meetings were held in FY 1999 (18 Oct. 98 and 24 Mar. 99). The committee critiqued the project's efforts and provided guidance and suggestions for ongoing and anticipated future refractories research.

CRITICAL ISSUES: Correlating the thermomechanical and thermophysical property dependencies on fusion-cast alumina microstructure will be paramount. The cast microstructure in the fusion-cast block is heterogeneous, and selected regions are sampled for testing. Consequently, accurately predicting the mechanical deformation of whole cast blocks using data generated in this project will be predicated on our successful choice of appropriate specimens.

FUTURE PLANS: More emphasis will be placed on corrosion and thermal property characterization of the remaining uncharacterized refractory categories (e.g., fusion-cast AZS, bonded zircon, fused silica, and bonded AZS.

POTENTIAL PAYOFF: More efficient and economical designs of glass-melting furnace superstructures will be a consequence of this project. Furnace superstructure designers will know which refractory brands perform better than others (from objectively generated data).

ESTIMATED ENERGY SAVINGS: Based on the 1998 DOE/OIT GPRA Report, approximately $\$ 202 \mathrm{M}$ in energy savings per year in 2005 and a $\$ 445 \mathrm{M}$ per year savings by 2020 will be realized with the conversion of air/fuel to oxy-fuel fired furnaces if $61 \%$ and $100 \%$ furnace conversions occur by 2005 and 2020, respectively. The results from this project will be used by glass manufacturers and their furnace designers to accelerate this conversion process. 


\section{SIGNIFICANT ACCOMPLISHMENTSADVANCED INDUSTRIAL MATERIALS (AIM) PROGRAM}

\section{Development of Improved Refractories}

ISSUE: There are numerous candidate commercially available refractories for use in glass-furnace superstructures; however, it is difficult for glass manufacturers to equitably judge them because the data almost always are generated or reported differently among vendors. The current project objectively generates high-temperature mechanical and thermophysical properties such that glass-manufacturing companies would be able to (1) compare performances of various refractories and (2) provide engineering data that furnace-design engineers could use for the optimizing the design of furnace superstructures.

RESULTS: Four different areas were investigated in FY 1999 that addressed the above issues. Completion of the test matrix of conventional silica refractories was completed in early FY 1999, and a ORNL/TM report was prepared in FY 1999. Second, two conventional silica bricks from float-glass and TV-panel furnaces were analyzed for changes to structure from their respective 10 and 6 years of service. Microstructural and phase changes were found and were a function of position away from the bricks' hot-face end. As a consequence of these changes, the bricks' thermal conductivity increased with the exception of those locations where substantial porosity was found. Third, the thermomechanical and thermophysical characterization of ten fused-grain mullite refractories (candidate refractory for borosilicate glass production) was initiated. Thermal conductivity and corrosion analyses were completed. Finally, the thermomechanical and thermophysical characterizations of two fusion-cast alumina refractories (best candidates for oxy-fuel fired furnaces) were initiated. Thermal-conductivity measurements have been completed, and the creep performances are being examined as a function of block position (i.e., microstructure) as well as temperature and stress.
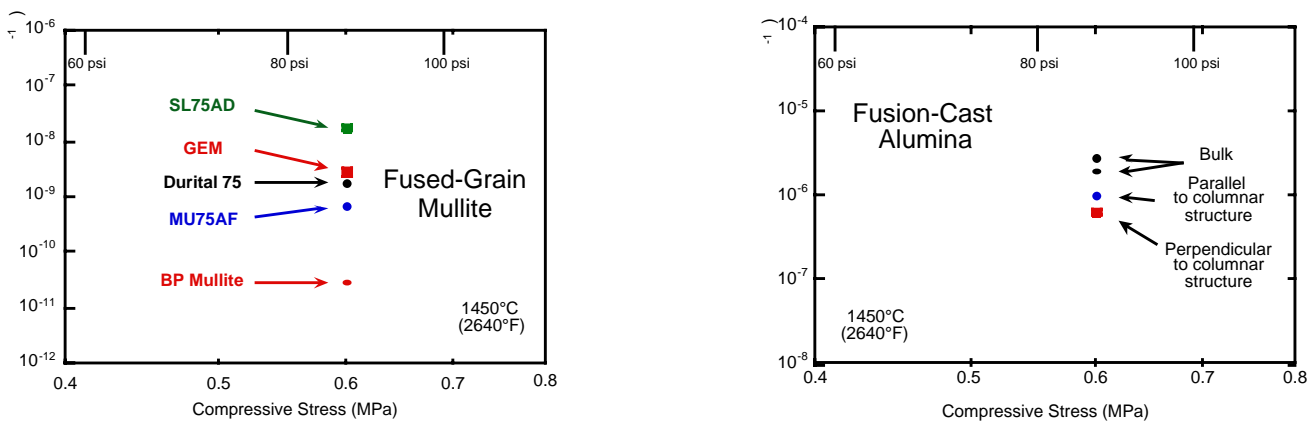

Fig. 1. Creep Comparison of Mullites and Fusion-Cast Aluminas

ENERGY EFFICIENCY: Based on the 1998 DOE/OIT GPRA Report, approximately $\$ 202 \mathrm{M}$ in energy savings per year in 2005 and a $\$ 445 \mathrm{M}$ per year savings by 2020 will be realized with the conversion of air/fuel to oxy-fuel fired furnaces if $61 \%$ and $100 \%$ furnace conversions occur by 2005 and 2020, respectively. The results from this project will be used by glass manufacturers' furnace designers to accelerate this conversion process. 



\section{Advanced Industrial Materials (AIM) Program}

\section{PROJECT TITLE: Metals Processing Laboratory User (MPLUS) Facility}

PHASE: FY 1999

COMPLETION DATE: December 31, 1999

PERFORMING ORGANIZATION: Oak Ridge National Laboratory (ORNL)

PRINCIPAL INVESTIGATOR: G. Mackiewicz-Ludtka (423-576-4652)

PHASE OBJECTIVE: Continue to partner with DOE Vision Industries and Universities by providing access to the unique technical expertise and facilities at MPLUS.

ULTIMATE OBJECTIVE: To assist U.S. industries in improving energy efficiency and enhance their competitiveness in the global market by partnering with national laboratories.

TECHNICAL APPROACH: Started as a small-scale, pilot User Facility Program in February 1996, the initial goal of MPLUS was to determine whether a need existed for such a program and, if so, to demonstrate its value. Based on continued and everincreasing industrial and academic requests and demands, the MPLUS Program has demonstrated that there is a growing need for the unique technical expertise and facilities accessible through the MPLUS Program.

PROGRESS: As of September 30, 1999, a total of 135 MPLUS Proposals were received from 72 companies and universities representing states all across the United States, and 40 MPLUS projects have been completed. The continued and increasing demand for and the success of the MPLUS facilities are evidenced by (a) the number of users (72 companies); (b) the 24 organizations who requested repeated assistance and submitted multiple (2 to 4) proposals for different MPLUS projects; and (c) the 4 companies who chose to do proprietary (P) MPLUS projects, paying full-cost-recovery to access MPLUS. In addition a total of 1071 user days were logged during FY 1999. This tremendous response to the MPLUS program continues to demonstrate, through the continually increasing numbers of industrial requests, that U.S. industry approves and supports the mission of the MPLUS program, and that these companies view the MPLUS Program as beneficial in achieving their corporate missions. In fact, with the growing response and needs being identified via MPLUS, the program is a viable vehicle/mechanism to unite other national laboratory user facilities to provide industry with a mechanism to access these national resources as a virtual laboratory.

Patents: ERID0344

Books: None
Publications: 15

Presentations: $\sim 15$
Proceedings: 1

Awards: 1 


\section{PROJECT SUMMARY (continued)}

\section{PROJECT TITLE: Metals Processing Laboratory User Facility (MPLUS)}

\section{ACCOMPLISHMENTS:}

Licenses: None

Known Follow-On Product(s): Company dependent

Technology Transfer or Industrial Interaction: Technical transfer and industrial interactions are what MPLUS is about. Technology transfer activities occur with every project.

CRITICAL ISSUES: Can national laboratories be a valuable asset to U.S. industries by providing unique and valuable input to materials processing issues so that U.S. industries can reclaim their competitive edge in the global market?

FUTURE PLANS: Continue to expand MPLUS to incorporate additional, needed facilities and expertise available at other sites.

POTENTIAL PAYOFF: Improving energy efficiencies and development of U.S. industry's competitive edge in the global market by providing a platform for enhanced relationships and partnerships among industries, academia, and National Laboratories. MPLUS also provides a mechanism for transferring R\&D technologies into industrial arenas.

ESTIMATED ENERGY SAVINGS: Energy savings vary with the individual project. Some, such as infrared-related projects, can and do realize immediate savings. They not only save energy, but also replace, reduce, and, at times, eliminate manufacturing processes that otherwise also would have a negative impact on the environment. 


\section{SIGNIFICANT ACCOMPLISHMENT}

\section{ADVANCED INDUSTRIAL MATERIALS (AIM) PROGRAM}

\section{The Metals Processing Laboratory User (MPLUS) Facility}

ISSUE: Continue pilot test of the Metals Processing Laboratory User (MPLUS) Facility

RESULTS: As of September 30, 1999, a total of 135 MPLUS Proposals were received from 72 different companies and universities representing numerous U.S. states (Fig. 1).

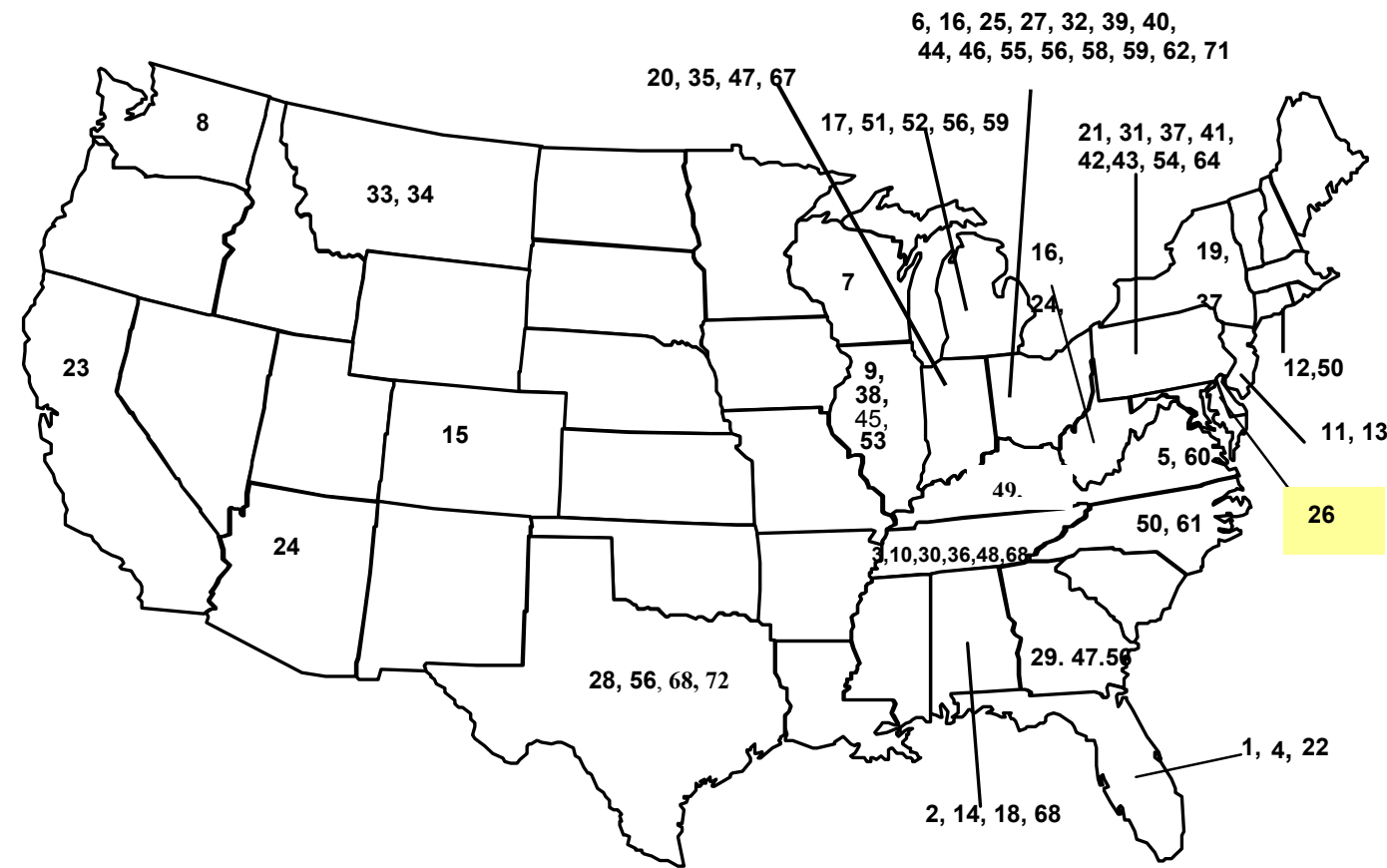

1. Westinghouse (3)

2. Reynolds (3)

3. ForMat Industries

4. US Filter

5. E. R. Johnson

6. Sandusky Int'l

7. Waukesha Electric

8. Weyerhauser (2)

9. A. Finkl (3)

10. Jeffrey Chain Corp

11. Materials Tech.

12. ABB C-E Serv. (3)

13. Union Camp Corp

14. United Defense (2)

15. CO Sch. of Mines (2)

16. Weirton Steel

17. General Motors (2)

18. Univ. of AL (2)
19. Cornell Univ.

20. Cummins Eng. (3)

21. Bethlehem Steel (2)

22 Anchor Glass

23. FMC Corp.

24. WV Univ. (2)

25. Dana Corp

26. Westvaco

27. Lincoln Electric (2)

28. CarboMedics

29. IPST

30. Univ. of TN (2)

31. PPG industries (4)

32. Owens Corning (2)

33. Columbia Falls Al

34. AFFCO

35. Allison Engine

36. TTE Die Castings
37. Alcoa Aluminum

38. Wagner Castings

39. Rhenium Alloys

40. Uniform Metal Tech.

41. Univ. of Pittsburgh

42. J\&L Specialty Steel

43. Penn State Univ.

44. Finite Solutions

45. Caterpillar

46. General Electric (2)

47. Southwire Co.

48. Smelter Services

49. Stoody

50. Torrington Research (2)

51. Ford Motor Co. (3)

52. Eaton (2)

53. Hoskins Mfg. (2)

54. AHT Inc.
55. DCT, Inc. Intl. (5)

56. Amercord

57. INCO Alloys

58. LTV Steel

59. Amer. Axle

60. VA Poly. \& St. U.

61. Torrington-Shiloh

62. Int'l Paper

63. Citation

64. Lehigh Univ.

65. ARCO

66. Equistar Chem., LP

67. Haynes Int'l (5)

68. Eastman Chem. (3)

69. Azko Chemical

70. Special Metals Inc.

71. GMTI-Lester

72. Exxon

ENERGY EFFICIENCY: This amount is different for each individual MPLUS project.

Research sponsored by the U.S. Department of Energy, Assistant Secretary for Energy Efficiency and Renewable Energy, Office of Industrial Technologies, Advanced Industrial Materials Program, under contract DE-AC05-00OR22725 with UT-Battelle, LLC. 



\section{PROJECT SUMMARY}

\section{ADVANCED INDUSTRIAL MATERIALS (AIM) PROGRAM}

PROJECT TITLE: Microwave Joining of SiC

PHASE: FY 1999

COMPLETION DATE:

PERFORMING ORGANIZATION: FM Technologies, Inc.

PRINCIPAL INVESTIGATOR: Richard Silberglitt (703-425-5111)

PHASE OBJECTIVE: To understand the nature of the $\mathrm{SiC}$ interlayer formed in situ from polymer precursor pyrolysis during microwave joining of $\mathrm{SiC}$ materials and to develop effective joining slurries.

ULTIMATE OBJECTIVE: To identify and develop the most effective microwave joining methods for scale-up to large tube assemblies of silicon carbide that are required for industrial applications.

TECHNICAL APPROACH: SiC was formed in situ by decomposition of polymer precursor slurries in a microwave applicator evacuated and backfilled with inert gas. The quality of the $\mathrm{SiC}$ formed from different slurries was investigated via X-ray diffraction and joints were made between commercial tubes using a polymer precursor slurry to form a SiC layer in situ.

PROGRESS: SiC was produced from several different slurries of the same preceramic polymer with different carbon loadings. The crystal development of the $\mathrm{SiC}$ was comparable to that produced using conventional heating, suggesting that the higher sensitivity to polymer carbon content previously observed in microwave heating of different polymers is not simply a function of carbon content. Sections of commercial reaction bonded $\mathrm{SiC}$ radiant burner tubes supplied by the manufacturer were joined and provided to the manufacturer for leak testing.

$\begin{array}{lll}\text { Patents: None } & \text { Publications: } 1 & \text { Proceedings: None } \\ \text { Books: None } & \text { Presentations: } 3 & \text { Awards: } 1\end{array}$

\section{ACCOMPLISHMENTS:}

\section{Licenses: None Known Follow-On Product(s): None Industry Workshop: None}

Technology Transfer or Industrial Interaction: Industrial-sponsored program under development with Stone \& Webster to join pairs of 15-ft-long sintered SiC tube sections to form furnace coils for testing in a prototype high-temperature furnace in an ethylene production plant. Testing under way at Schunk-Inex for application to reaction-bonded $\mathrm{SiC}$ radiant burner tube assemblies. 


\section{PROJECT SUMMARY (continued)}

PROJECT TITLE: Microwave Joining of SiC

CRITICAL ISSUES: Development of applicators for cost-effective fabrication of industrial size specimens and a full suite of mechanical strength data including service environment.

FUTURE PLANS: Joining of test specimens supplied by industrial collaborators that properly simulate the components to be fabricated, followed by tests conducted by the industrial collaborators that simulate performance environments, and then scale up to fabricate prototype components and prototype testing. Commercialization agreements will be based upon licensing or contract manufacturing, as appropriate.

POTENTIAL PAYOFF: The markets for SiC radiant burner tubes and heat exchangers have been estimated to be greater than $\$ 100 \mathrm{M}$ annually. These components cannot currently be cost-effectively fabricated in the lengths and shapes required. Microwave joining could be an enabling technology by allowing fabrication through the joining of several small, simply shaped pieces. Development of a transportable microwave applicator would provide the capability for on-site fabrication and repair of ceramic tube assemblies.

ESTIMATED ENERGY SAVINGS: One hundred billion cubic feet of natural gas is consumed each year in approximately 25,000 heat-treating furnaces that use primarily metal radiant burner tubes. Replacement with ceramic tubes would drastically reduce or eliminate tube-replacement cost and enable savings of almost $\$ 200,000$ per furnace per year through increased efficiency of higher-temperature operation. Use of a $\mathrm{SiC}$ tube heat exchanger in externally fired combined-cycle coal power plants is projected to produce a $20 \%$ increase in thermal efficiency. Energy savings through the reduction of feedstock consumption and decoke fuel and steam requirements with an advanced ethylene production process using a high-pressure $\mathrm{SiC}$ heat exchanger are projected at 63.9 trillion Btu per year. 


\section{SIGNIFICANT ACCOMPLISHMENT}

\section{ADVANCED INDUSTRIAL MATERIALS (AIM) PROGRAM}

\section{Microwave-Joined SiC Radiant Burner Tubes Pass Commercial Leak Rate Test}

ISSUE: Replacement of high-temperature metal alloy radiant burner tube assemblies with $\mathrm{SiC}$ tubes will produce significant energy and cost savings and reduce environmental impact. Joining is required to fabricate tube assemblies that are longer than commercially available SiC tubes and that include bends that cannot be fabricated cost-effectively as a single component.

RESULTS: Commercial reaction-bonded $\mathrm{SiC}$ tube sections provided by the manufacturer were joined using microwave hybrid (microwave plus radiant) heating of a commercial polymeric precursor to form a $\mathrm{SiC}$ interlayer in situ. The joined tube sections were provided to the manufacturer and tested for hermeticity at the manufacturing facility. The leak rate was determined to be below that which would be detectable in service as a radiant burner tube.

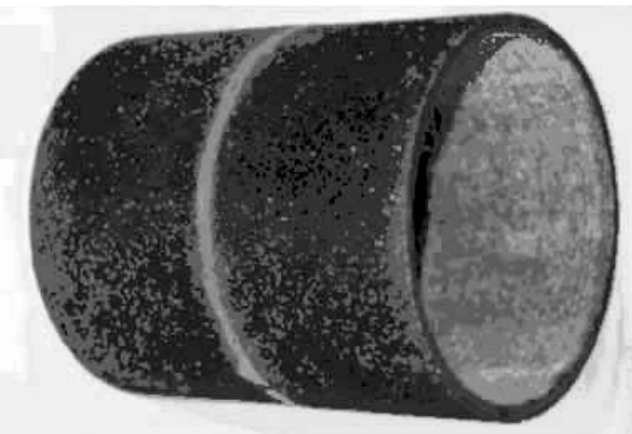

Fig. 1. Photograph of commercial radiant burner tubes supplied by Schunk-Inex and joined at FM Technologies using microwave hybrid heating. Length of joined tube section is approximately $10.16 \mathrm{~cm}(4 \mathrm{in}$.$) and tube outer$ diameter is approximately $8.255 \mathrm{~cm}$ (3.25 in.) with a wall thickness of approximately $3 \mathrm{~mm}$ (1/8 in.).

ENERGY EFFICIENCY: One hundred billion cubic feet of natural gas is consumed each year in approximately 25,000 heat-treating furnaces that use primarily metal radiant burner tubes. Replacement with ceramic tubes would drastically reduce or eliminate tube replacement cost and enable savings of almost \$200,000 per furnace per year through increased efficiency of higher-temperature operation. Use of $\mathrm{SiC}$ tube heat exchanger in externally fired combined-cycle coal power plants is projected to produce a $20 \%$ increase in thermal efficiency. Energy savings through the reduction of feedstock consumption and decoke fuel and steam requirements with an advanced ethylene production process using a high-pressure $\mathrm{SiC}$ heat exchanger are projected at 63.9 trillion Btu per year.

Research performed at FM Technologies, Inc., sponsored by the U.S. Department of Energy, Assistant Secretary for Energy Efficiency and Renewable Energy, Office of Industrial Technologies, Advanced Industrial Materials Program. Tubes and leak testing provided by Schunk, Inex Corporation, Holland, New York. 



\section{PROJECT SUMMARY}

\section{ADVANCED INDUSTRIAL MATERIALS (AIM) PROGRAM}

\section{PROJECT TITLE: SELECTIVE INORGANIC THIN FILMS \\ PHASE: FY 1999 \\ COMPLETION DATE:}

PERFORMING ORGANIZATIONS: Sandia National Laboratories (SNL), New Mexico State University (NMSU), University of Aberdeen (UA) (includes effort funded by OIT Chemical Vision Team)

PRINCIPAL INVESTIGATOR: Tina M. Nenoff/(SNL) (505-844-0340)

PHASE OBJECTIVE: Model, synthesize, and characterize novel inorganic composite Zeolite/sol-gel thin-film membranes for light-gas via molecular sieving. Confine permeability of film to zeolite crystals by increasing density of coverage and reducing gas permeability of matrix. Enhance permeability by decreasing film thickness while maintaining continuous coverage.

ULTIMATE OBJECTIVE: Develop new class of inorganic membranes for hydrocarbon and light gas separations, and possibly catalysis. Use this technology to improve upon separation efficiencies and thermal stability currently available with polymer or oxide membranes, emphasizing application to petroleum and natural gas refining. Transfer technology base to industry.

TECHNICAL APPROACH: Use computational modeling to select appropriate microporous phases for desired separation. Nucleate and crystallize zeolite and microporous phosphate-based phases via hydrothermal synthesis methods, using porous filters and gas membranes as supports for these films. Investigate novel microporous zinc phosphates as molecular sieves.

PROGRESS (FY 1999): During FY 1999 we have successfully synthesized defect-free zeolite/sol-gel composite thin-film membranes on a number of different substrates. The films are thermally stable up to $500^{\circ} \mathrm{C}$. The choice of molecular species for various target light-gas or hydrocarbon molecule separations were determined by molecular modeling of pore sizes and shapes. We also have developed a new technology, for which we have submitted a patent, of gas impermeable end seals that are stable on membrane supports over many thermal and mechanical stress cycles. These end seals are durable to at least $1000^{\circ} \mathrm{C}$.

\section{ACCOMPLISHMENTS:}

Publications: 4 Presentations: 4 Disclosures: 1

Licenses: None Known Follow-On products: None Industry Workshops: None 


\section{PROJECT SUMMARY (continued)}

\section{PROJECT TITLE: SELECTIVE INORGANIC THIN FILMS}

CRITICAL ISSUES: (1) Develop defect-free inorganic composite zeolite/sol-gel membranes for specific light-gas and hydrocarbon separations. (2) Develop gasimpermeable end sealant technology for high-temperature permeation testing.

FUTURE PLANS: (1) Transfer funding support from DOE/AIM to a CRADA partner for the end seals technology. This DOE/AIM program will continue to support the modeling, synthesis/characterization and industrial scaleup of composite inorganic Zeolite/Sol-gel thin films for specific light-gas and hydrocarbon molecule separations. (2) Model the diffusion of binary mixtures of light gases (e.g., $\mathrm{H}_{2}, \mathrm{CO}_{2}, \mathrm{H}_{2} \mathrm{O}, \mathrm{CH}_{4}$, and $\mathrm{CH}_{3} \mathrm{OH}$ ) in novel microporous systems and then synthesize and validate the designs in the production of thin, leak-free membranes containing microporous phosphate-based phases (e.g., Gallo-zinc phosphates and Boron/organic zinc phosphates). (3) Develop amorphous hybrid organic-inorganic molecular sieving membranes for gas purification and hydrogen recovery.

POTENTIAL PAYOFF: The petroleum and natural gas refining industries would significantly benefit from high-permeability molecular sieve films capable of separating light, fixed gases, particularly if the membranes can be used at high temperatures. The alkali metal zinc phosphates that we have synthesized as membranes are stable up to $700^{\circ} \mathrm{C}$, which is compatible with hydrogen recovery. With sufficiently high permeability and low unit area cost, energy savings of several quad/year could be achieved when all feasible applications of inorganic membranes are considered.

We are currently developing partnerships with BP Amoco to develop the end seals technology for membranes further (ongoing discussions with Dr. Terry Mazanec, BP Amoco Chemicals). We have further discussions with Goodyear Tire and Rubber Company for potential partnerships in membrane technology for specific molecular separation needs (ongoing discussions with Dr. Jeffrey Goodwin, Chemical Research and Development). 


\section{SIGNIFICANT ACCOMPLISHMENTS}

\section{ADVANCED INDUSTRIAL MATERIALS (AIM) PROGRAM}

\section{Membranes for Light-Gas and Hydrocarbon Separations}

DEFECT-FREE SELECTIVE MEMBRANES: Defect-free crystalline/amorphous composite thin-film membranes have been developed. These membranes are shape and size selective for various light-gas and hydrocarbon molecules. A combination of molecular modeling, chemical synthesis, and validation testing has enabled us to make these membranes. To date, defect-free membranes that have separation values for $\mathrm{N}_{2} / \mathrm{SF}_{6}$ $>2000$ have been produced. Synthesis of new bulk microporous molecular sieve phases and then convert them into thin film membranes is continuing.

End Seal Technology: A new technology has been developed: Gas-Impermeable End Seals, which have (1) long life through many temperature and mechanical cycles, (2) are stable to high temperatures (at least $1000^{\circ} \mathrm{C}$, and (3) are chemically inert to membrane synthesis. We have submitted a patent request for this material and are currently in negotiations with industry for a 100\% funds-in-kind CRADA. The CRADA will allow us to further develop and commercialize this technology.

DOE/Vision 2020: The Chemical Industry: In September 1998, our CRADA team was awarded a 3-year, \$4.295M grant for Energy and Waste Minimization Research Supportive of Technology Vision 2020: The Chemical Industry project is titled "Advanced Materials for Reducing Energy Consumption and Manufacturing Costs in the Chemicals and Petroleum Refining Industries." This project is ongoing with BP Amoco (formerly Amoco Chemicals) and Coors Technical Ceramics Corporation. To date, two patents originating from this program have been submitted.

Research sponsored by the U.S. Department of Energy, Assistant Secretary for Energy Efficiency and Renewable Energy, Office of Industrial Technologies, Advanced Industrial Materials Program, under contract DE-AC04-95AL85000 and at the BP Amoco Corporation. Sandia is a multiprogram laboratory operated by Sandia Corporation, a Lockheed Martin Company, for the United States Department of Energy. 



\section{POLYMERS}





\section{PROJECT SUMMARY}

\section{ADVANCED INDUSTRIAL MATERIALS (AIM) PROGRAM}

\section{PROJECT TITLE: Polymer Electrolyte Electrochemical Reactors of Lowered Energy Consumption}

PHASE: FY 1999

COMPLETION DATE:

PERFORMING ORGANIZATION: Los Alamos National Laboratory

PRINCIPAL INVESTIGATOR: Shimshon Gottesfeld (505-667-0853)

PHASE OBJECTIVES: Reach stable performance for 3 months with chlor-alkali electrochemical reactor (ECR) employing an oxygen cathode, exhibiting cell voltage lower by at least, $30 \%$ vs present-day industrial chlor-alkali ECR, at the ordinary current density of $300 \mathrm{~A} / \mathrm{ft}^{2}$. Alternatively, higher throughputs (as high as $1000 \mathrm{~A} / \mathrm{ft}^{2}$ ) are to be demonstrated, while still maintaining a significant fraction of the energy savings.

ULTIMATE OBJECTIVES: Optimize materials for the promising new cell design to answer combined requirements of mechanical and chemical stability in the context of industrial-size cells. Develop and test electrochemical reactor (ECR) employing such materials/structures for the chlor-alkali industry, based on an oxygen or air electrode, demonstrating energy consumption lower by $30 \%$ vs the current industrial chlor-alkali ECR at same product throughput and at current efficiency $>90 \%$.

TECHNICAL APPROACH: Novel ECR configuration, based on effective oxygen cathodes developed at LANL, are assembled and tested at LANL. Optimization is based on detailed analysis of losses in the cell and on modification of cell materials and elements following identification of sources of loss. Collaboration with Dow Chemical ensures meaningful comparison with current technology. Materials examination regarding mechanical- and corrosion-susceptibility characteristics is performed under the most relevant, well-defined conditions, employing both electrochemical and other analytical techniques.

PROGRESS: *A new cell configuration introduced by us in 1999, has provided high performance and performance stability of a chlor-alkali ECR with oxygen cathode. By introducing a new flow-field element in the cathode structure, in the form of surfacecoated, patterned metal foil, we managed to enhance by full order of magnitude the duration of perfectly stable operation of oxygen depolarized chlor-alkali cells. At the same time, we have proven viability of elements that would replace the need for costly machining (the element is "nonmachined") and pointed to possible choices of materials (and surface coatings) that would enable problem-free scaleup all the way to industrial dimensions. Patent application on the unique cathode structure has been submitted (December 1999). 


\section{PROJECT SUMMARY (continued) \\ PROJECT TITLE: Polymer Electrolyte Electrochemical Reactors of Lowered Energy Consumption}

ACCOMPLISHMENTS: We strongly believe that the most recent results demonstrated with the new chlor-alkali ECR based on oxygen cathode are very unique. Information is not available on any comparable achievement in terms of unique ECR structure, the high energy savings, and the possibility of much higher throughput per cell size while still maintaining a significant fraction of the energy saving.

CRITICAL ISSUES: The most critical issue in this project is demonstration of very long term, stable performance in operation in energy saving mode based on an oxygen cathode. Performance stability depends, in turn, on optimization of cathode structure and cell operation conditions. The oxygen cathode requires moving away from the materials and flow field employed in initial ECR demonstration to material and structures that will provide satisfactory mechanical properties. This must occur in an actual cell several feet high and several feet wide, while providing, at the same time, high cell performance (lower voltages). Significant steps have been made in this direction this year. The natural choice of metallic components from mechanical perspective will have to be followed by judicious choice of metal components with or without surface treatment that can withstand the caustic environment and the potential of an oxygen cathode.

FUTURE PLANS: Continue to resolve key materials and structures issues of the advanced, energy-saving $/ \mathrm{CO}_{2}$ emission-cutting ECR technology developed jointly between LANL and Dow Chemical. Implement such material in cell of increasing size, in testing at both LANL and Dow Chemical

POTENTIAL PAYOFF: (1) Potential to save up to 50\% of the electric energy consumed by an industry that uses $2 \%$ of the total electric power generated in the United States. (2) Introduction of new chlor-alkali reactor technology giving U.S. industry a competitive edge. (3) Cutting $\mathrm{CO}_{2}$ emissions by up to $50 \%$ in an industry that is a major consumer of electric power.

ESTIMATED ENERGY SAVINGS: Potential to save up to 50\% of the electric energy consumed by an industry that uses $2 \%$ of the total electric power generated in the United States. 


\section{SIGNIFICANT ACCOMPLISHMENT}

\section{ADVANCED INDUSTRIAL MATERIALS (AIM) PROGRAM}

\section{Energy Efficient Electrochemical Reactors (ECRs)}

PROBLEM: The chlor-alkali industry consumes $2 \%$ of the total electric power generated in the United States. The products at the cathode are $\mathrm{NaOH}$ and hydrogen gas, and gaseous chlorine is generated at the anode. The cell voltage directly reflects the electric energy consumption per ton of chlorine (or caustic) product. Lowering of the cell voltage is, therefore, an important energy savings target for this particular industrial process, as well as several other industrial processes involving electrochemical oxidations.

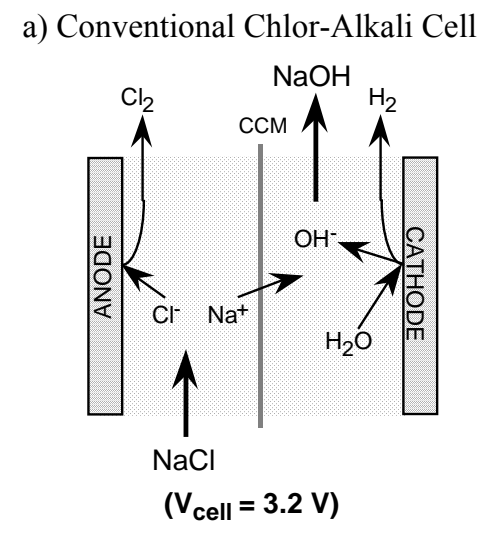

b) Chlor-Alkali Cell with Oxygen Cathode

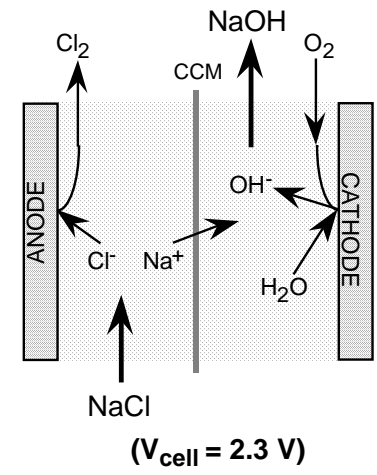

RESULTS: The figure on the left shows the conventional configuration of an ECR used in the chlor-alkali industry, generating chlorine and caustic soda by electrolysis of sodium chloride brine. The cell voltage required at typical production rate of $300 \mathrm{~A} / \mathrm{ft}^{2}$ is 3.2 to $3.3 \mathrm{~V}$. If the hydrogen-evolving cathode were replaced by an oxygen-consuming cathode (b), the voltage of the cell could be reduced, in principle, by about $0.9 \mathrm{~V}$. In recent years, advanced oxygen/air electrodes have been developed, and adaptation of elements of the approach for chlor-alkali ECRs seems possible. Interest at Dow Chemical resulted in a CRADA agreement between Dow Chemical and LANL. This joint LANL/Dow technical work was augmented in November 1998 by further funding from OIT (Chemical Industry), which we committed to enhanced testing and technologytransfer activities. Materials science and technology issues continue to be addressed.

A new cell configuration, introduced in FY 1999, provided very high throughput of a chlor-alkali ECR with oxygen cathode, while maintaining significant electric energy savings. The newest, 1999 version enabled us, for the first time, to extend duration of stable operation from hundreds to thousands of hours. The new cell element introduced also has the advantages of scalability to industrial dimensions and low-cost manufacturing.

Energy Efficiency: (1) Potential to save 33\% of the electric energy consumed by an industry that uses $2 \%$ of the total electric power generated in the United States (plus a corresponding lowering in $\mathrm{CO}_{2}$ emissions).

R\&D performed at Los Alamos National Laboratory (LANL) under the sponsorship of DOE-EE-OIT, Advanced Industrial Materials Program. 



\section{Internal Distribution}

1. Central Research Library

2-3. ORNL Laboratory Records RC/OSTI

4. P. Angelini

5. G. M. Sims

6. A. C. Schaffhauser

\section{External Distribution}

7-8. U.S. Department of Energy/Headquarters, 1000 Independence Avenue, S.W., Washington, DC 20585

Douglas E. Kaempf, EE-24, 6A-116/FORS

Henry Kenchington, EE-23, 6B-025/FORS

Marsha L. Quinn, EE-23, 6B-025/FORS

Scott L. Richlen, EE-21, 6B-025/FORS

Charles A. Sorrell, EE-23, 5F-059/FORS

Denise F. Swink, EE-20, 6B-025/FORS

9. U.S. Department of Energy/Oak Ridge, Oak Ridge National Laboratory, Building 4500N, Mail Stop 6269, P.O. Box 2008, Oak Ridge, TN 37831-6269

Mary H. Rawlins 